Article

\title{
Zircon U-Pb Dating and Petrogenesis of Multiple Episodes of Anatexis in the North Dabie Complex Zone, Central China
}

\author{
Yang Yang ${ }^{1}$, , Yi-Can Liu ${ }^{1} * \mathbb{C}$, Yang $\mathrm{Li}^{1}{ }^{1}$, Chiara Groppo ${ }^{2,3}$ and Franco Rolfo ${ }^{2,3}$ \\ 1 CAS Key Laboratory of Crust-Mantle Materials and Environments, School of Earth and Space Sciences, \\ University of Science and Technology of China, Hefei 230026, China; chanming@mail.ustc.edu.cn (Y.Y.); \\ ly20115@mail.ustc.edu.cn (Y.L.) \\ 2 Department of Earth Sciences, University of Torino, 1-10125 Torino, Italy; chiara.groppo@unito.it (C.G.); \\ franco.rolfo@unito.it (F.R.) \\ 3 Consiglio Nazionale delle Ricerche-Istituto di Geoscienze e Georisorse, Section of Torino, \\ 1-10125 Torino, Italy \\ * Correspondence: liuyc@ustc.edu.cn; Tel.: +86-551-6360-0367
}

Received: 5 June 2020; Accepted: 6 July 2020; Published: 9 July 2020

\begin{abstract}
The North Dabie complex zone (NDZ), central China, is a high-T ultrahigh-pressure (UHP) metamorphic terrane. It underwent a complex evolution comprising of multistage metamorphism and multiple anatectic events during the Mesozoic continental collision, characterized by granulite-facies overprinting and a variety of migmatites with different generations of leucosomes. In this contribution, we carried out an integrated study including field investigation, petrographic observations, zircon U-Pb dating, and whole-rock element and $\mathrm{Sr}-\mathrm{Nd}-\mathrm{Pb}$ isotope analysis for the migmatites in the NDZ and their leucosomes and melanosomes. As a result, four groups of leucosomes have been recognized: Group 1 (garnet-bearing leucosome), strongly deformed leucosomes with coarse-grained peritectic garnet; Group 2 (amphibole-rich leucosome), weakly deformed to undeformed amphibole-rich leucosomes with coarse-grained peritectic amphibole and no garnet; Group 3 (amphibole-poor leucosome), weakly deformed to undeformed amphibole-poor leucosomes with minor fine-grained amphibole; Group 4 (K-feldspar-rich leucosome), K-feldspar-rich leucosomes mainly composed of coarse-grained quartz, plagioclase and K-feldspar. Zircon SHRIMP and LA-ICPMS U-Pb dating suggest that the Group 1 leucosomes formed at $209 \pm 2$ Ma whereas the rest of the leucosome groups (Groups 2-4) occurred between 145-110 Ma, in response to decompression under granulite-facies conditions during the early stage of exhumation, and to heating during post-orogenic collapse, respectively. Furthermore, the garnet-bearing leucosomes were resulted from fluid-absent anatexis related to biotite dehydration melting, while the other three groups of leucosomes were formed during large-scale fluid-present partial melting and coeval migmatization. This migmatization comes from heating from the mountain-root removal and asthenosphere upwelling, together with the influx of fluids derived from country rocks at mid-upper crustal levels. However, all the leucosomes and melanosomes display Pb-isotopic compositions similar to those observed for the NDZ UHP rocks (eclogites and granitic gneisses), suggesting a common source from the Triassic subducted Neoproterozoic lower-crustal rocks. In addition, the Cretaceous partial melting and migmatization began at $143 \pm 2 \mathrm{Ma}$ with three age-peaks at $133 \pm 3 \mathrm{Ma}, 124 \pm 3 \mathrm{Ma}$ and $114 \pm 7 \mathrm{Ma}$, respectively.
\end{abstract}

Keywords: zircon; anatexis; leucosome; crustal exhumation; post-orogenic collapse 


\section{Introduction}

Partial melting (anatexis) plays an important role during continental collision and crustal evolution $[1,2]$ because it significantly influences continental crust differentiation and subducted crust exhumation [3-5], and even finally leads to orogenic collapse [6,7]. Anomalous heat sources, rapid decompression or fluid-influx [3] would induce crustal rocks to partially transform from solid to liquid across critical points [8-13]. The occurrence of melts can dramatically affect the geomechanical properties of the crust (e.g., density, rheology, element migration and components segregation) [14-17] of the crust and can modify the original structures and textures.

Generally, partial melting of crustal rocks in collisional orogens occurs during the initial stages of exhumation and/or during post-orogenic collapse [1,5,18-21], mainly involving in decompression and/or pushing rock packages up the geotherm. Generation of granitic melts and their transfer from the lower/middle crust to the upper crust is a complex sequence of physical and chemical processes that occur at different scales and different rates [3,17]. Migmatites are the most common high-grade metamorphic products representing the anatexis of source rocks $[3,22,23]$. Despite the existence of different protoliths, partial melting reactions produce a relatively limited number of mineral assemblages, depending on the P-T-X conditions in which the melt occurs, preserved within different types of leucosomes [24-26]. Thus, the study of the leucosomes can provide important information on the nature of the anatectic melts and therefore represent a window into the processes and mechanisms of crustal anatexis [27]. Thereby, the identification, characterization and accurate dating of leucosomes are crucial for revealing the nature of the post-collisional evolution of an orogen involving the exhumation of deeply subducted slices, as well as for the mountain-root collapse $[6,7]$.

The North Dabie complex zone (NDZ) within the Dabie orogen, central China, is an ideal natural laboratory to study partial melting processes in the lower/middle crust. It is characterized by abundant high-T $\left(>850^{\circ} \mathrm{C}\right)$ metamorphic rocks of lower crustal origin, including tonalitic to granitic gneisses and minor retrograded eclogite lenses [28-30]. Migmatites derived from tonalitic to granitic orthogneisses are widespread in the NDZ and contain various generations of granitic leucosomes and dykes [31-33]. Previous zircon $\mathrm{U}-\mathrm{Pb}$ dating suggested that the tonalitic to granitic gneisses and migmatites here have Neoproterozoic precursor ages and Triassic subduction-related metamorphic ages, and most of the leucosomes within the migmatites were formed at 145-120 Ma [34-38]. It is therefore generally assumed that the migmatites in the NDZ recorded large-scale Cretaceous anatexis [29,32,34-36,39] resulting from mountain-root delamination and, hence, the generation of the leucosomes are related to the post-orogenic history of the Dabie orogen.

Some NDZ migmatites also contain anatectic zircons with late Triassic U-Pb ages [29,36], suggesting that the NDZ probably experienced an earlier anatectic event during the late Triassic. However, no direct petrological evidence of late-Triassic anatexis have been reported so far from the migmatites of the NDZ. Appealing clues for the existence of different episodes of anatexis within the NDZ have been given by the investigations on the eclogites, indicating that there are two episodes of anatexis including decompression melting at $207 \pm 4 \mathrm{Ma}$ and heating melting at $\sim 130 \mathrm{Ma}$ that took place during the early stage of exhumation and post-orogenic collapse [5,40-42], respectively.

The leucosomes and melanosomes from the NDZ migmatites are still poorly known, especially studies with a focus on geochronology and isotopic geochemistry; this paper aims to fill this gap, providing detailed field and petrographic observations, coupled with geochronological and element-isotope data on various leucosomes and related rocks in the NDZ. The main aim is to find unambiguous petrological evidence confirming the existence of different widespread anatectic events within the NDZ, so far documented only in the eclogites, and to explore the elemental and isotopic behavior of the system during the leucosomes' formation.

The obtained results will allow clarification of multiple episodes of anatexis that may be produced by different mechanisms and that occurred during the early stage of exhumation as well as during post-orogenic collapse. Furthermore, peritectic garnet-bearing leucosomes are reported for the first 
time in the region. Overall, this study aims to outline a detailed petrogenesis of partial melting processes responsible for the formation of different generations of leucosomes in the NDZ.

\section{Geological Setting and Samples}

\subsection{The North Dabie Complex Zone}

The Dabie orogen is located at the middle part of the Central Orogenic Belt of China formed by northward subduction of the South China Block beneath the North China Block in Triassic [43,44]. It consists of a series of fault-bounded rock units with various metamorphic grades and evolutional histories [45,46], and especially contains one of the most extensive, exposed and well-preserved ultrahigh-pressure (UHP) metamorphic terranes in the world. Generally, the Dabie orogen can be subdivided into five lithotectonic units from south to north [28,45,47,48]: (1) the Susong complex zone (SZ); (2) the South Dabie low-T eclogite zone (SDZ); (3) the Central Dabie mid-T/UHP metamorphic zone (CDZ); (4) the North Dabie high-T/UHP complex zone (NDZ); (5) the Beihuaiyang zone (BZ) (Figure 1). These zones are separated by the Xiaotian-Mozitan fault, Wuhe-Shuihou fault, Hualiangting-Mituo fault (XMF) and Taihu-Shanlong fault (WSF), respectively.

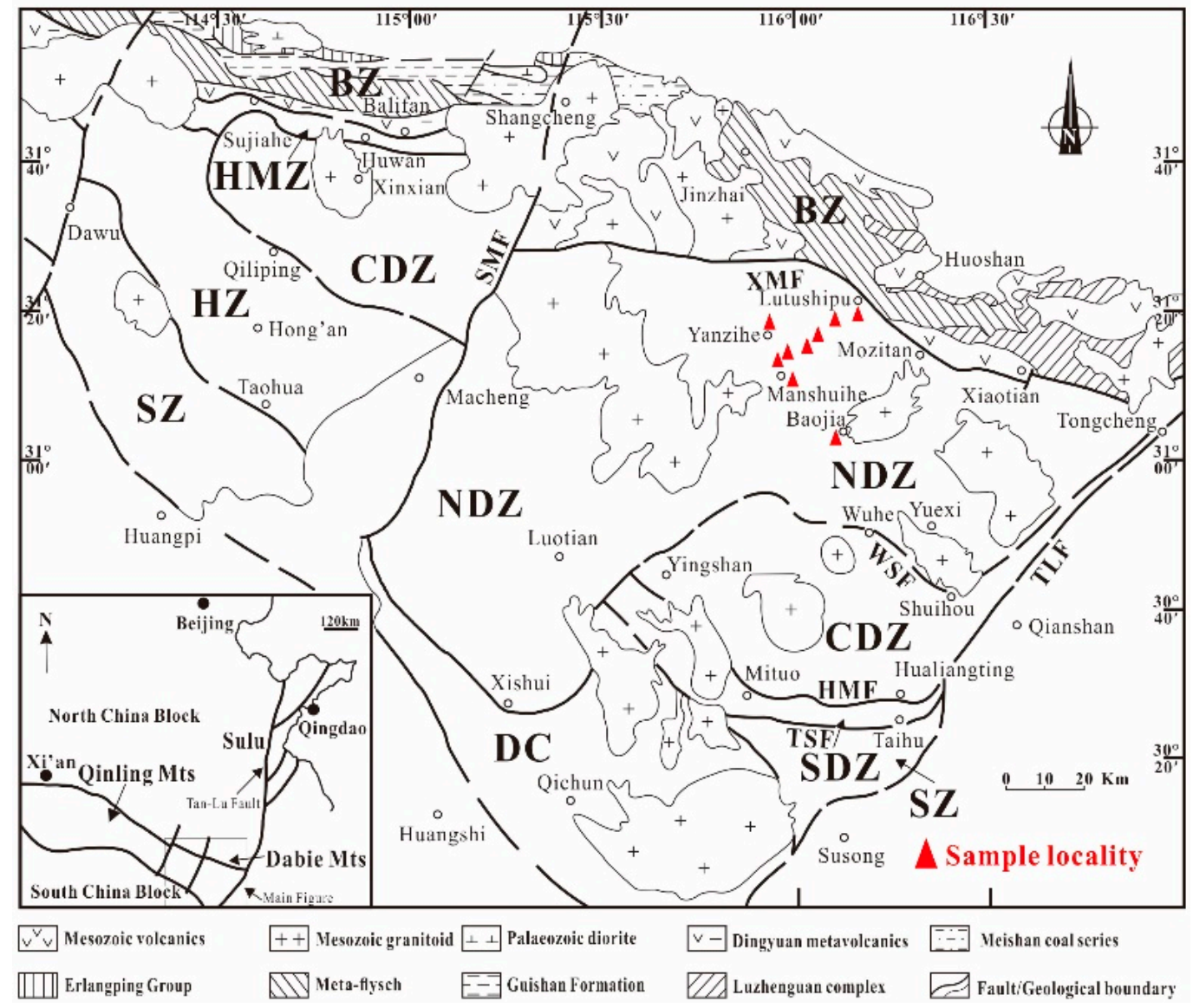

Figure 1. Schematic geological map of the Dabie orogen, with inset showing the location of this area within the Triassic Qinling-Dabie-Sulu collision orogen in central China (modified from [28]). Sample localities are marked by red triangles. BZ, Beihuaiyang zone; NDZ, North Dabie complex zone; CDZ, Central Dabie UHP metamorphic zone; SDZ, South Dabie LT eclogite zone; SZ, Susong complex zone; HMZ, Huwan mélange zone; HZ, Hong'an LT eclogite zone; DC, amphibolite-facies Dabie complex; XMF, Xiaotian-Mozitan fault; WSF, Wuhe-Shuihou fault; HMF, Hualiangting-Mituo fault; TSF, Taihu-Shanlong fault; TLF, Tan-Lu fault; SMF, Shangcheng-Macheng fault.

The SDZ, CDZ and NDZ are three eclogite-bearing UHP units of the Dabie orogen [28,29,44,47-56]. Isotope dating of various UHP rocks (e.g., eclogite and gneiss) widespread in all the three units 
$[28,29,43,50,52,57]$ suggested that they experienced UHP metamorphism during deep subduction of the South China Block in the Triassic. Nevertheless, the NDZ is different from the other two UHP units in two main aspects [5]. Firstly, the NDZ underwent an additional long-lasting high-T granulite-facies metamorphic overprint while the SDZ and CDZ only underwent amphibolite-facies retrogression after eclogite-facies metamorphism [42,45]. Secondly, migmatites, especially stromatic migmatites with various leucosomes [32,35] are widespread in the NDZ.

The NDZ is located between the BZ and CDZ, separated by the XMF to the north and by the WSF in the south, respectively (Figure 1). The NDZ mainly consists of tonalitic and granitic orthogneisses and post-collisional Cretaceous intrusions with subordinate meta-peridotite, garnet pyroxenite, garnet-bearing amphibolite, granulite and eclogite. The NDZ has been documented to be involved in deep subduction, and underwent UHP metamorphism and subsequent multistage retrogression during exhumation $[28,47,48,51,58,59]$. In the meantime, the meta-igneous rocks (i.e., granitic orthogneiss and eclogite) in the region have been identified to have Neoproterozoic protolith ages (770-800 Ma) [28,47,48,51,58,59]. On the other hand, the occurrence of widespread stromatic migmatites indicates that the younger large-scale partial melting and migmatization took place in the NDZ. In addition, many post-collisional igneous intrusions emplaced in the area during the Cretaceous are also related to the extension and collapse of the Dabie orogen $[39,60]$.

\subsection{Stromatic Migmatites and Leucosome Samples}

The NDZ hosts the largest exposure of migmatites in the Dabie orogen, as mentioned above. The migmatites are highly variable in morphology and composition and are ubiquitous in the region. Diatexites are mainly exposed in the west such as in the Luotian dome, while metatexites (mainly stromatic migmatites) are widespread in the middle and eastern parts of the NDZ. Stromatic migmatites are characterized by numerous, thin, parallel and laterally persistent neosomes (Figures 2 and 3). Moreover, the stromatic migmatites are generally cut by late Cretaceous potassium-rich veins and dykes. Leucosomes within the NDZ stromatic migmatites can be roughly subdivided into four main groups based on field occurrences, mineral assemblages and geochemical compositions (see below in detail): (1) garnet-bearing leucosomes; (2) amphibole-rich leucosomes; (3) amphibole-poor leucosomes; (4) K-feldspar-rich leucosomes (Figure 3).
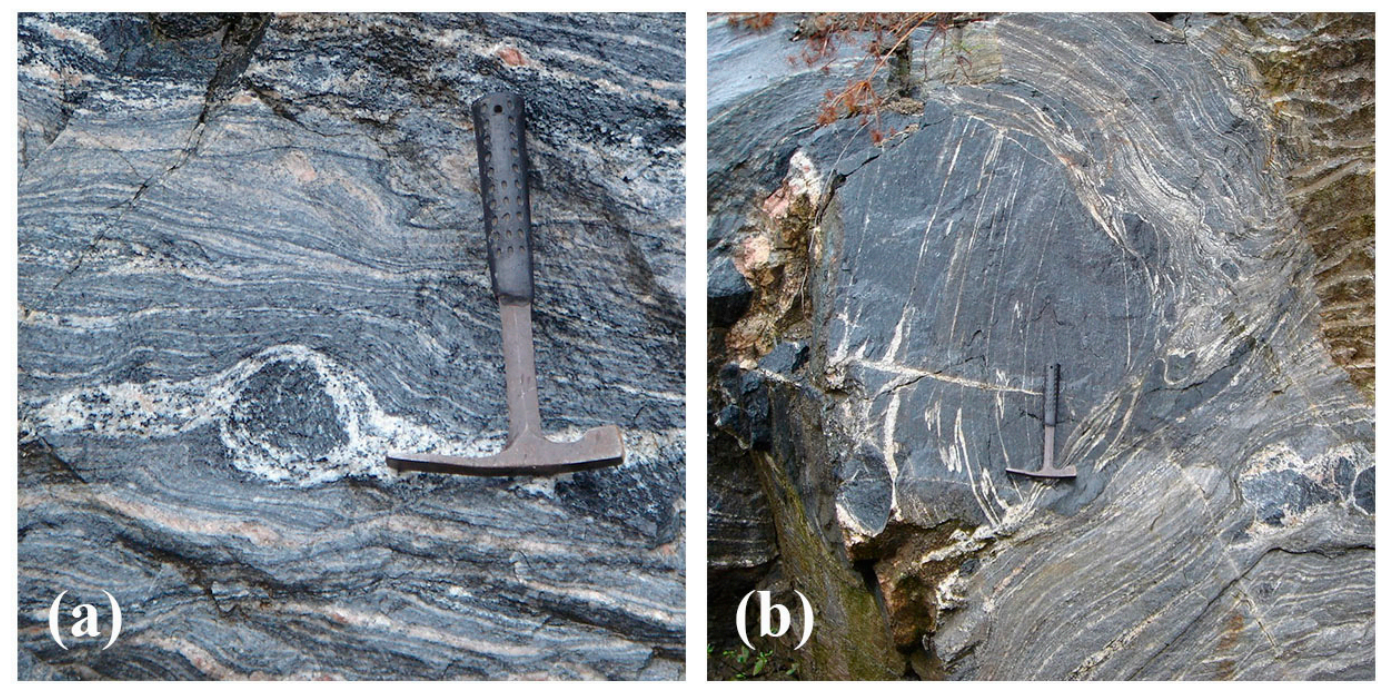

Figure 2. Field photographs showing various generations of leucosomes within the migmatites from the NDZ. (a) Many amphibole-bearing and K-feldspar-rich leucosomes within the stromatic migmatites. (b) Amphibolite metatexites with leucocratic veins enclosed by grey schilieren diatexites. 

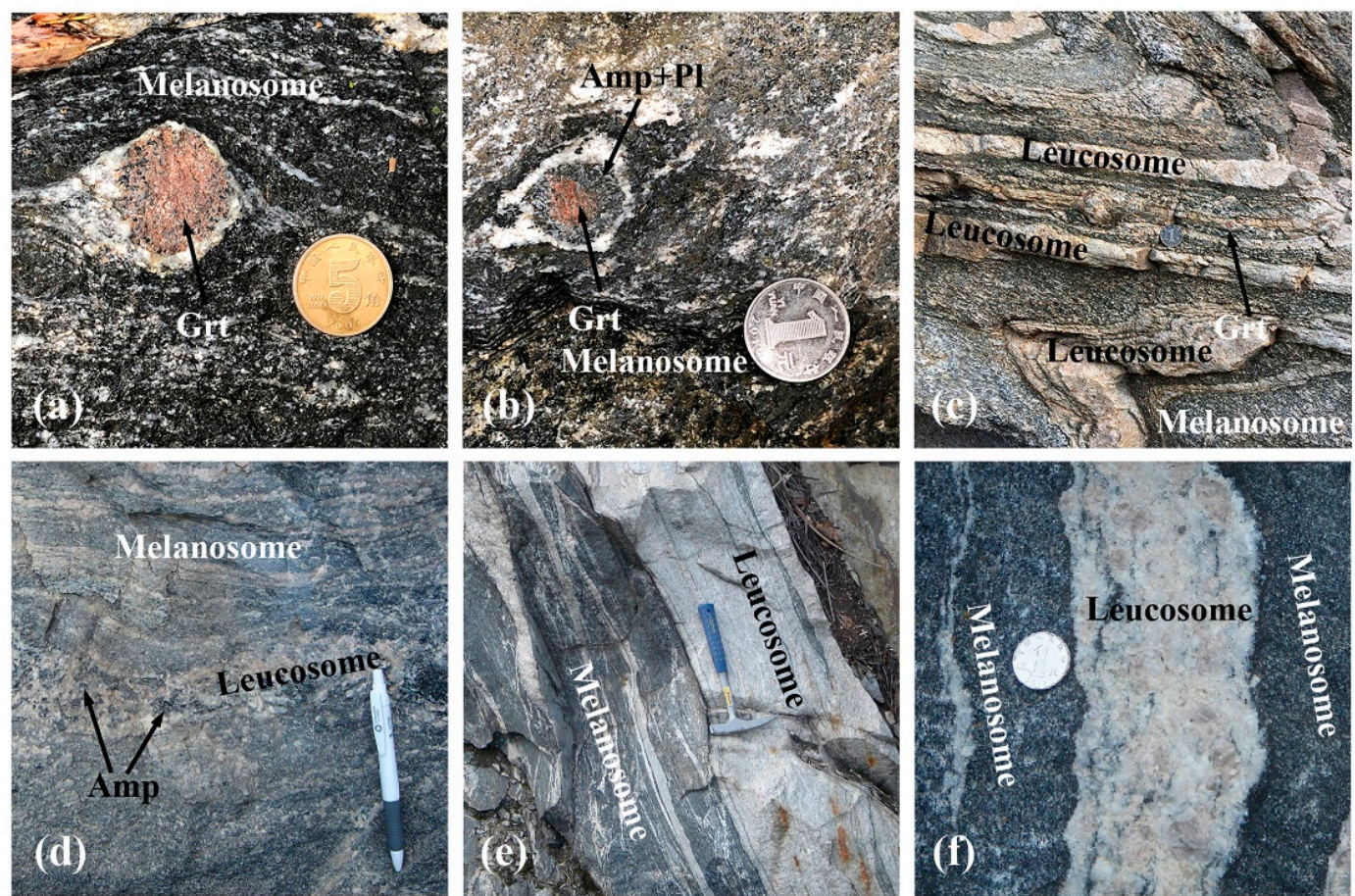

Figure 3. Field photographs showing four groups of leucosomes within the migmatites from the NDZ: (a) garnet-bearing leucosome patch with peritectic garnets surrounded by $\mathrm{Qz}+\mathrm{Pl}$ rims; (b) garnet-bearing leucosome patch with peritectic garnets surrounded by double rims (Amp $+\mathrm{Pl}$ and $\mathrm{Qz}+\mathrm{Pl}$ ); (c) garnet-bearing leucosomes with strong fold deformation; (d) amphibole-rich leucosome with peritectic amphibole; (e) amphibole-poor leucosome; (f) K-feldspar-rich leucosome.

\subsubsection{Garnet-Bearing Leucosomes}

Garnet-bearing leucosomes are rarely exposed in the NDZ and generally coexist with other types of leucosomes in the migmatites. Grt-bearing leucosomes form networks variable in appearance and generally display in situ patches or in-source layers with scattered coarse-grained peritectic garnets or garnet aggregates (Figure $3 a, b$ ). The leucosomes are composed of garnet, amphibole, plagioclase, K-feldspar and quartz, with accessory ilmenite, apatite, titanite and zircon. The garnets are generally surrounded by symplectitic coronas composed of amphibole and plagioclase towards its rims (Figure $3 b$ ). The large euhedral garnet porphyroblasts contain multiphase inclusions of plagioclase (Pl) + quartz $(\mathrm{Qz}) \pm$ chlorite $(\mathrm{Chl})$ and display almandine decreasing and spessartite increasing contents from core to rim; they are interpreted as peritectic minerals. In situ Grt-bearing patches generally have diameters of several centimeters while the in-source leucocratic layers range in thickness from 0.1 to $2 \mathrm{~cm}$ and are strongly deformed and folded parallel to the adjacent melanosomes (Figure 3c). The leucosomes have sharp contacts with the host rock and show defined melanosome rims (Figure $2 b$ ). Moreover, the layers are occasionally crosscut by other types of leucosomes and by the late Cretaceous igneous intrusions.

Garnets in the leucosomes are characteristically euhedral to subhedral crystals from a 0.3- to 1.5-mm diameter (Figure 4a-f). Corroded garnet crystals have abundant quartz, plagioclase and $\mathrm{K}$-feldspar inclusions and are commonly surrounded by plagioclase and amphibole. K-feldspar is dispersed in the matrix and several microperthitic alkali feldspar grains show bleb- to string-type plagioclase exsolution textures (Figure 4g,h). Chlorite and allanite are present along crystal boundaries and cleavages. Moreover, peritectic garnets are commonly surrounded by double rims ( $\mathrm{Amp}+\mathrm{Pl}$ and $\mathrm{Qz}+\mathrm{Pl}$ ) (Figure 3b), suggestive of amphibolite facies retrogression. 

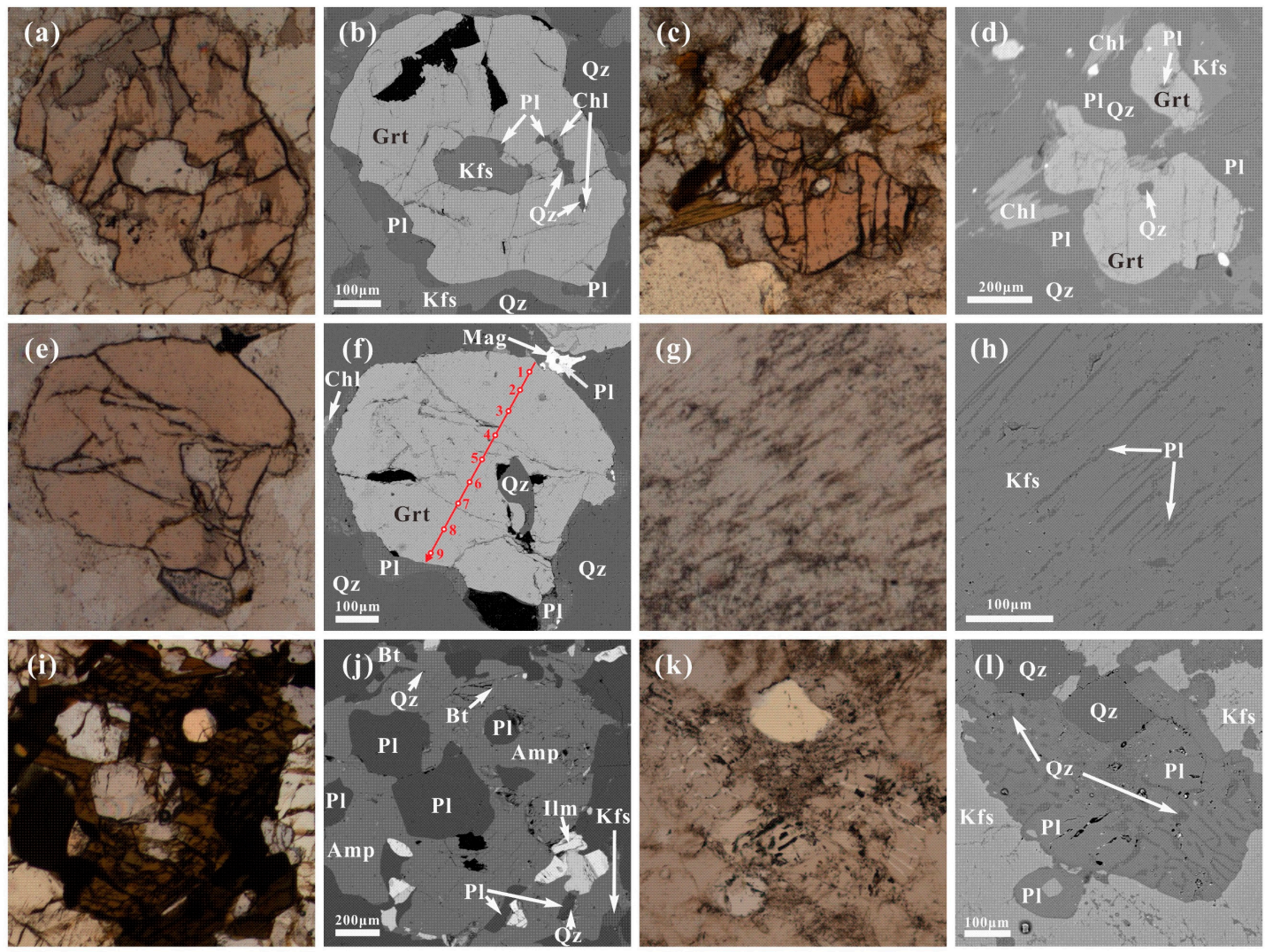

Figure 4. Photomicrographs and corresponding backscattered electron (BSE) images of various leucosomes from migmatites in the NDZ. $(\mathbf{a}, \mathbf{b})$ peritectic garnets with inclusions of quartz, plagioclase and chloritized biotite, surrounded by plagioclase rims, in Grt-bearing leucosome; (c,d) peritectic garnet with inclusions of plagioclase and quartz in Grt-bearing leucosome; chlorite occurs as pseudomorphs after biotite; (e,f) peritectic garnet with analytical profile by electron probe in Grt-bearing leucosome; analytical spots are marked by red circles; (g,h) Pl exsolutions in Kfs crystal in Grt-bearing leucosome;

$(\mathbf{i}, \mathbf{j})$ peritectic amphibole with inclusions of biotite, quartz and plagioclase in Amp-rich leucosome;

$(\mathbf{k}, \mathbf{l})$ myrmekitic texture with quartz exsolutions in plagioclase in Kfs-rich leucosome.

\subsubsection{Amphibole-Rich, Amphibole-Poor and K-Feldspar-Rich Leucosomes}

Amphibole-rich leucosomes are characterized by coarse-grained amphiboles in the leucocratic layers (Figure 3d). Amphiboles in the leucosomes are generally large and euhedral with rounded inclusions of quartz and plagioclase and are inferred to be peritectic products related to anatexis. Amphibole crystals are generally parallel to the foliation of migmatite, having a thickness of 1.5 to $15 \mathrm{~cm}$ and a length of over $1 \mathrm{~m}$. The leucosomes are composed of amphibole, biotite, plagioclase, quartz and K-feldspar, and zircon, titanite, Fe-oxides and Fe-sulphides occur as accessory minerals. Peritectic amphiboles display subhedral to euhedral shape and are coarse-grained with inclusions of biotite, plagioclase and quartz (Figure $4 \mathrm{i}, \mathrm{j}$ ).

Amphibole-poor leucosomes occur as in-source leucosomes or leucocratic veins and have mineral assemblages similar to those observed in the Amp-rich leucosomes, except that the amphiboles therein are much fewer and fine grained (Figure 3e). Moreover, layers of Amp-poor leucosomes generally range in thickness from 1.5 to $20 \mathrm{~cm}$ and extend over several meters. Both Amp-rich and -poor leucosomes contain chlorite and allanite but not garnet, and are weakly deformed to undeformed.

The K-feldspar-rich leucosomes are mainly quartz-feldspathic (Figure 3f) and consist of coarse-grained quartz, plagioclase and K-feldspar with minor chloritized biotite, with accessory zircon, titanite and magnetite. Most layers are leucocratic veins several tens of meters in length 
(Figure 3f), while few layers occur as in-source leucosomes. Kfs-rich leucosomes generally coexist with, or even cut through other leucosomes.

In comparison with the Grt-bearing leucosomes, Amp-rich, Amp-poor and Kfs-rich leucosomes are ubiquitous in the NDZ and generally display thick, flat, parallel leucocratic veins with diffuse boundaries to the host rock and no visible mafic selvedges. Different types of leucosomes commonly coexist in the same outcrop with mutual crosscutting relationships (Figure 2). Thus, the presence of multiple generations of leucosomes strongly suggests a complex anatectic history probably involving diverse processes and melting mechanisms [61].

\subsubsection{Sample Description}

Three Grt-bearing leucosome samples were collected from the Lutushipu and Manshuihe localities. Seven Amp-rich, four Amp-poor and three Kfs-rich leucosome samples were collected at Yanzihe, Manshuihe, Baojia and Lutushipu, respectively. Twelve melanosome samples adjacent to the abovementioned leucosomes were also collected from the same region. Besides, nine migmatites with segregated thin parallel neosome layers were sampled, including two leucocratic and seven melanocratic samples. Sampling localities are shown in Figure 1, and representative field photographs are provided in Figures 2 and 3.

\section{Analytical Methods}

\subsection{Whole-Rock Major and Trace Element Analysis}

Whole-rock major and trace element concentrations were determined at Langfang Laboratory of Geophysical Exploration, Geological Exploration Bureau of Hebei Province, Ministry of Land and Mineral Resources. Fresh rocks (38 samples) were first ground in an agate mill to less than 200 mesh for major and trace element analysis. Losses of ignition (LOI), $\mathrm{FeO}$ and $\mathrm{Fe}_{2} \mathrm{O}_{3}$ were determined by gravimetric, volumetric and titrimetric methods, whereas other major elements were determined by X-ray fluorescence (XRF) spectrometry with analytical precision better than $1 \%$. About $50 \mathrm{mg}$ powders of each sample were accurately weighed and dissolved in a 1:1 mixture of $\mathrm{HF}+\mathrm{HNO}_{3}$ at $190{ }^{\circ} \mathrm{C}$ using Parr bombs for $\sim 72 \mathrm{~h}$, and complete sample dissolution was achieved. The dissolved samples were diluted to $50 \mathrm{~mL}$ using $1 \% \mathrm{HNO}_{3}$ before analysis. Trace element analyses were accomplished using an inductively coupled plasma mass spectrometer (ICP-MS). Analytical precisions for trace elements are better than $5 \%$.

\subsection{Zircon $\mathrm{U}-\mathrm{Pb}$ Dating}

Zircons in leucosomes and melanosomes were separated from approximately 1 to $3 \mathrm{~kg}$ of each sample. After crushing and sieving, zircons were chosen by magnetic and heavy liquid separation and hand-picking under a binocular microscope at Langfang Laboratory of Geophysical Exploration, Geological Exploration Bureau of Hebei Province, Ministry of Land and Mineral Resources. Internal zoning patterns of zircon crystals were observed by cathodoluminescence (CL) images accomplished.

Zircon $\mathrm{U}-\mathrm{Pb}$ dating was performed in 5 samples using the sensitive high resolution ion micro probe II (SHRIMP II, ASI, Canberra, Australia) at the Beijing SHRIMP Centre, National Science and Techonology Infrastructure, Beijing, with a reference zircon U-Pb standard TEMORA 1 (417 Ma, [62]). Common $\mathrm{Pb}$ was corrected using the measured ${ }^{204} \mathrm{~Pb}$. The U-Pb isotope data were treated following [63] with the ISOPLOT program of [64]. Zircon U-Pb dating was also carried out by laser ablation (LA) ICP-MS at the CAS Key Laboratory of Crust-Mantle Materials and Environments, University of Science and Technology of China (USTC), Hefei. Standard materials 91500 and NIST610 were used as external calibrations for the $\mathrm{U}-\mathrm{Pb}$ ages and element concentrations. Zircon $\mathrm{U}-\mathrm{Pb}$ data and element contents were corrected by ICPMSDataCal (CUG, Wuhan, China) software $[65,66]$ and calculated using the Isoplot program [64]. 


\subsection{Whole-Rock $\mathrm{Rb}-\mathrm{Sr}, \mathrm{Sm}-\mathrm{Nd}$ and $\mathrm{Pb}$ Isotope Analyses}

Chemical separation processes and mass-spectrometer analyses of whole rock $\mathrm{Rb}-\mathrm{Sr}, \mathrm{Sm}-\mathrm{Nd}$ and $\mathrm{Pb}$ isotopes were performed at the CAS Key Laboratory of Crust-Mantle Materials and Environments, USTC, Hefei. Sample powder was weighed and mixed with ${ }^{87} \mathrm{Rb}-{ }^{84} \mathrm{Sr}$ and ${ }^{147} \mathrm{Sm}-{ }^{150} \mathrm{Nd}$ spikes prior to dissolution in concentrated $\mathrm{HF}-\mathrm{HNO}_{3}$ for one week in a clean laboratory. Chemical separation was performed on conventional ion exchange resin columns. Whole-rock $\mathrm{Rb}-\mathrm{Sr}, \mathrm{Sm}-\mathrm{Nd}$ and $\mathrm{Pb}$ concentrations and $\mathrm{Rb}-\mathrm{Sr}, \mathrm{Sm}-\mathrm{Nd}$ and $\mathrm{Pb}$ isotopic ratios were measured on a multi-collector Finnigan MAT-262 thermal ionization mass spectrometer (TIMS, Finnigan, Bremen, Germany) in static mode in the Laboratory for Radiogenic Isotope Geochemistry, USTC. The Sr and Nd isotope ratios were normalized to ${ }^{86} \mathrm{Sr} /{ }^{88} \mathrm{Sr}=0.1194$ and ${ }^{146} \mathrm{Nd} /{ }^{144} \mathrm{Nd}=0.7219$, respectively, to correct for mass fractionation. During the data collection period, repeated measurements on the NBS987 Sr standard solution yielded an average ${ }^{87} \mathrm{Sr} /{ }^{86} \mathrm{Sr}$ value of $0.710239 \pm 12(2 \sigma)$, and the La Jolla $\mathrm{Nd}$ standard solution gave an average ${ }^{143} \mathrm{Nd} /{ }^{144} \mathrm{Nd}$ value of $0.511870 \pm 8(2 \sigma)[67,68]$. Mass dependent fraction for Pb isotope ratios was $0.1 \%$ per atomic mass unit based on repeated analyses of NBS 981 standard measurements $[67,68]$.

\subsection{Mineral Composition Analysis}

Mineral compositions were measured in the experimental center at the School of Resources and Environmental Engineering, Hefei University of Technology with a JEOL JXA-8230 electron microprobe (EMP, JEOL Ltd., Tokyo, Japan) operating at a $15-\mathrm{kV}$ accelerating voltage. The analysis was performed using a specimen current of $20 \mathrm{nA}$ and a beam diameter of $3 \mu \mathrm{m}$. The accuracy and precision of most elements was estimated to be better than $2 \%$. Mineral abbreviations through the text including figures and tables are after Whitney and Evans [69].

\section{Results}

\subsection{Whole-Rock Major and Trace Elements}

Major and trace element contents of the four groups of leucosomes, melanosomes and the two types of migmatite samples selected from the NDZ are presented in Supplementary Table S1 and illustrated in Figures 5 and 6.
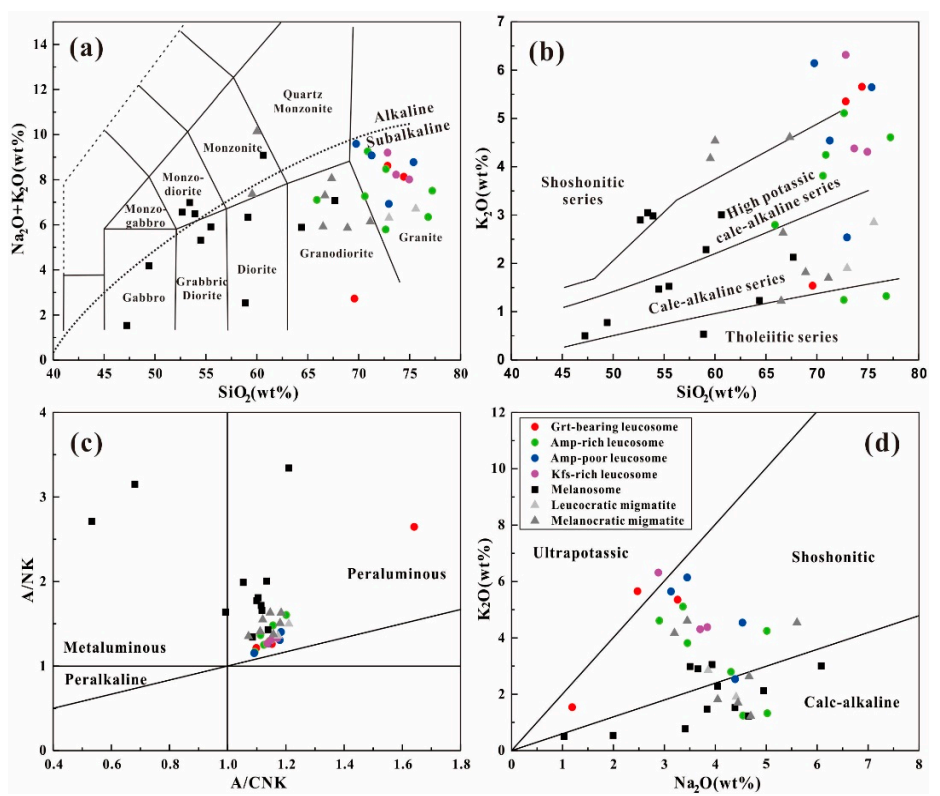

Figure 5. Major elements scatter diagrams of the studied leucosomes and corresponding melanosomes in the NDZ migmatites. (a) total alkalies vs. silica (TAS) diagram; (b) $\mathrm{SiO}_{2}$ vs. $\mathrm{K}_{2} \mathrm{O}$ diagram; (c) $\mathrm{A} / \mathrm{CNK}$ vs. A/NK diagram; (d) $\mathrm{Na}_{2} \mathrm{O}$ vs. $\mathrm{K}_{2} \mathrm{O}$ diagram. 

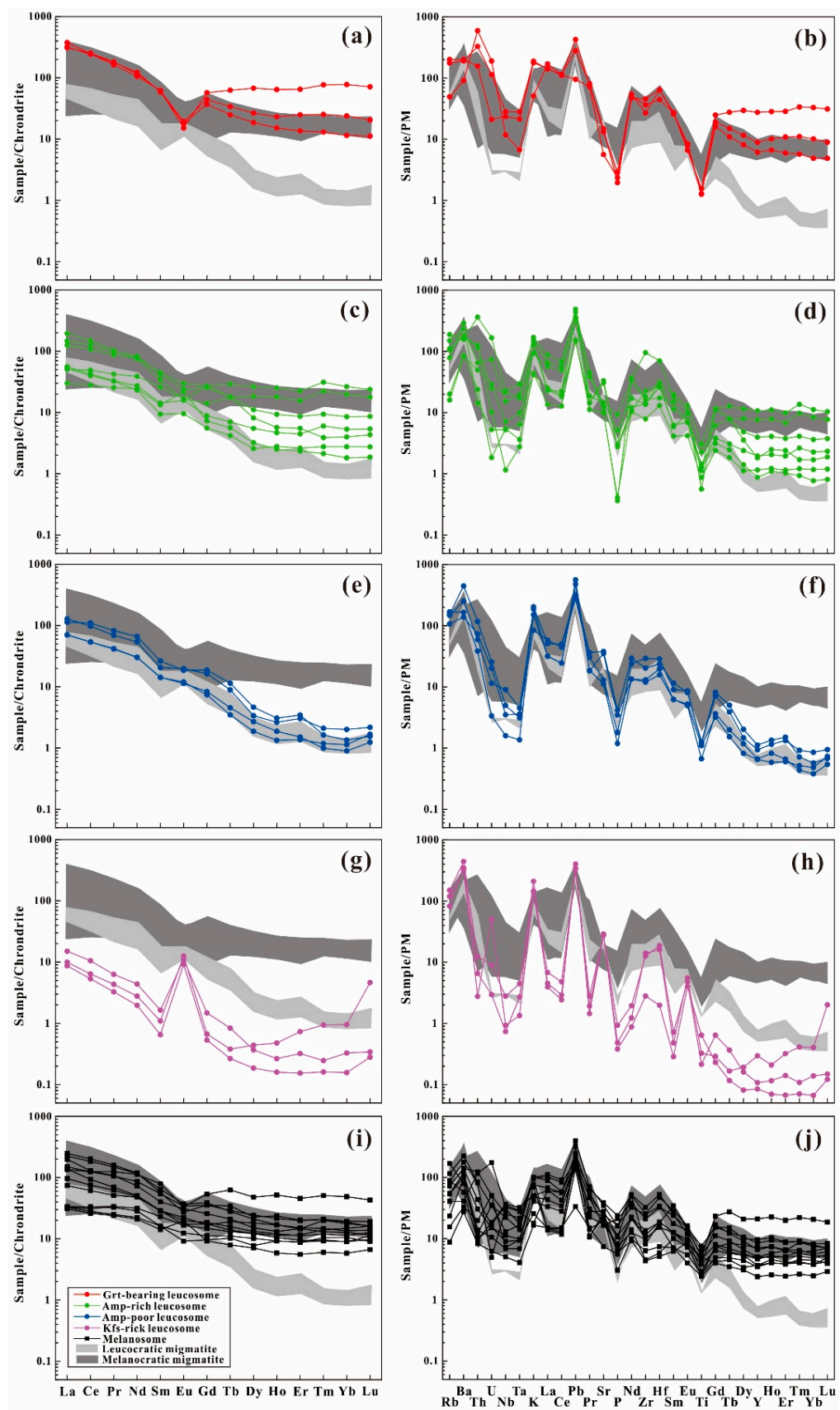

Figure 6. Whole-rock chondrite-normalized REE patterns and corresponding primitive mantle (PM)-normalized trace element patterns for various leucosomes and melanosomes of migmatites in the NDZ. Normalized values of REEs and trace elements are from [70,71], respectively. (a) REE patterns of Grt-bearing leucosomes; (b) trace elements patterns of Grt-bearing leucosomes; (c) REE patterns of Amp-rich leucosomes; (d) trace elements patterns of Amp-rich leucosomes; (e) REE patterns of Amp-poor leucosomes; (f) trace elements patterns of Amp-poor leucosomes; (g) REE patterns of Kfs-rich leucosomes; (h) trace elements patterns of Kfs-rich leucosomes; (i) REE patterns of melanosomes; (j) trace elements patterns of melanosomes. All the present data are from this study.

All leucosomes in the NDZ stromatic migmatites exhibit sub-alkaline affinities plotting mainly in the granite and granodiorite field with $\mathrm{SiO}_{2}$ contents ranging from 65.58 to 77.23 wt.\% on the TAS diagram (Figure 5a). Most samples are slightly peraluminous with A/CNK values of 1.09-1.64 (Figure 5c); most of them plot in the calc-alkaline to shoshonitic series fields over a wide range of $\mathrm{K}_{2} \mathrm{O}$ contents in the $\mathrm{K}_{2} \mathrm{O}$ vs. $\mathrm{SiO}_{2}$ and $\mathrm{K}_{2} \mathrm{O}$ vs. $\mathrm{Na}_{2} \mathrm{O}$ diagrams (Figure $5 \mathrm{~b}$,d). 
Grt-bearing leucosomes have slightly lower $\mathrm{Al}_{2} \mathrm{O}_{3}$ (9.59-13.54 wt.\%) and $\mathrm{Na}_{2} \mathrm{O}$ (1.19-3.26 wt.\%), higher $\mathrm{K}_{2} \mathrm{O}$ (1.54-5.65 wt.\%), $\mathrm{FeO}_{\mathrm{T}}(1.87-11.33$ wt.\%), $\mathrm{MgO}(0.31-0.73$ wt.\%) and $\mathrm{MnO}(0.05-0.33$ wt.\%) contents, and lower Mg\# values (9.50-23.94) as compared to other groups of leucosomes. However, the remaining three types of leucosomes have similar $\mathrm{Al}_{2} \mathrm{O}_{3}, \mathrm{TiO}_{2}, \mathrm{CaO}, \mathrm{MnO}$ and $\mathrm{Na}_{2} \mathrm{O}$ contents while $\mathrm{FeO}_{\mathrm{T}}$ (with an average of 2.11, 1.47 and 0.57, respectively) and $\mathrm{MgO}$ (with average of 0.80, 0.35 and 0.15 , respectively) contents progressively decrease with $\mathrm{K}_{2} \mathrm{O}$ contents (with average of 3.34, 4.71 and 5.00, respectively) increasing from Amp-rich to Amp-poor and to Kfs-rich leucosomes. Melanosomes are characterized by significantly higher $\mathrm{Al}_{2} \mathrm{O}_{3}$ (6.06-21.55 wt.\%), $\mathrm{TiO}_{2}\left(0.54-1.64\right.$ wt.\%), $\mathrm{CaO}\left(2.95-15.40\right.$ wt.\%), $\mathrm{FeO}_{\mathrm{T}}(3.05-10.60$ wt.\%), $\mathrm{MgO}$ (1.72-19.21 wt.\%) and lower $\mathrm{SiO}_{2}$ (47.24-67.68 wt.\%) and $\mathrm{K}_{2} \mathrm{O}(0.50-3.05$ wt.\%) contents. Most melanosomes plot in the peraluminous field with $\mathrm{A} / \mathrm{CNK}$ ranging from 1.00 to 1.21. Two metalluminous samples (1310YZH7-1 and $1310 \mathrm{YZH}$ 7-2) do not follow the main trends as a result of their high CaO contents (10.05 and $15.40 \mathrm{wt.} \%$, respectively).

On chondrite-normalized rare earth element (REE) diagrams [70], both leucosome and melanosome samples exhibit right-incline patterns with variations in Eu anomalies, REE contents and fractionations between LREE and HREE (Figure 6). All the samples are enriched in LILEs (e.g., Rb, Sr and Ba) and depleted in HFSEs (e.g., $\mathrm{Nb}, \mathrm{Ta}, \mathrm{Zr}, \mathrm{Hf}$ and $\mathrm{Th}$ ) on primitive mantle-normalized trace element spider diagrams [71] (Figure 6). Grt-bearing leucosomes are characterized by the highest total REE contents (427-492 ppm), weakly fractionated REE patterns $\left(\mathrm{La}_{\mathrm{N}} / \mathrm{Yb}_{\mathrm{N}}=4.86-27.79\right.$, where $\mathrm{N}$ represent chondrite-normalized values), notable negative Eu anomalies $\left(\delta_{\mathrm{Eu}}=0.25-0.39\right)$, the lowest $\mathrm{Sr} / \mathrm{Y}$ ratios (1-10) and high Y contents (Figures 6 and 7). Amp-rich and -poor leucosomes have similar total REE contents (58-263 and 95-188 ppm, respectively) and $\mathrm{Sr} / \mathrm{Y}$ values (6-122 and 64-251, respectively) and exhibit no distinct Eu anomalies ( $\delta_{\mathrm{Eu}}=0.54-2.19$ and 0.83-1.17, respectively) (Figures 6 and 7). However, Amp-poor leucosomes display strongly fractionated REE patterns with $\mathrm{La}_{\mathrm{N}} / \mathrm{Yb}_{\mathrm{N}}$ ranging from 62.14 to 84.26, while Amp-rich leucosomes have higher HREE contents and lower $\mathrm{La}_{N} / \mathrm{Yb}_{\mathrm{N}}$ ratios (2.56-36.89) (Figure 7). Kfs-rich leucosomes show remarkably positive Eu anomalies $\left(\delta_{\mathrm{Eu}}=10.48-55.56\right)$ with the lowest total REE contents (10-18 ppm) and the highest Sr/Y ratios (454-1553) among all groups of leucosomes (Figures 6 and 7). Moreover, melanosomes adjacent to different leucosomes show relatively uniform and slightly fractionated REE patterns with medium total REE contents (58-373 ppm) and $\mathrm{La}_{\mathrm{N}} / \mathrm{Yb}_{\mathrm{N}}$ ratios (2.78-16.72). Melanosomes also exhibit light to insignificant Eu anomalies with $\delta_{\mathrm{Eu}}$ varying from 0.74 to 1.73 (Figures 6 and 7).
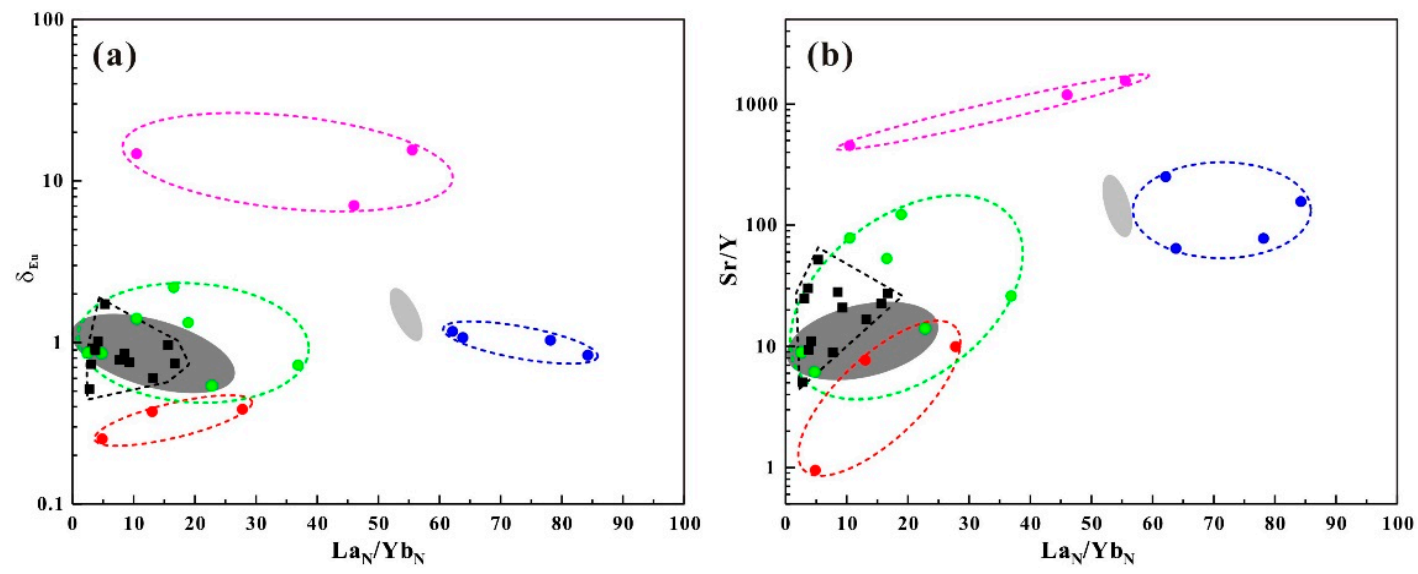

Figure 7. Whole-rock scatter diagrams of various leucosomes and melanosomes of migmatites in the NDZ. (a) La $\mathrm{N}_{\mathrm{N}} / \mathrm{Yb}_{\mathrm{N}}$ vs. $\delta_{\mathrm{Eu}}$ diagram; (b) La $\mathrm{N} / \mathrm{Yb}_{\mathrm{N}}$ vs. $\mathrm{Sr} / \mathrm{Y}$ diagram. Other symbols are the same as in Figure 6. 


\subsection{Zircon CL Images and $U-P b$ Dating}

Seven samples of leucosomes and three samples of melanocratic migmatites were selected for zircon U-Pb dating and the results are listed in Supplementary Table S2 (by SHRIMP) and Table S3 (by LA-ICPMS).

Zircons from Grt-bearing leucosomes (sample 1310YZH1-1 and 1310YZH6-1) are subhedral to anhedral, short prismatic to equant and colorless, ranging in size from 70 to $200 \mu \mathrm{m}$. The CL images reveal a core-mantle-rim texture (Figure 8a-d). In sample 1310YZH 6-1, irregular zircon cores exhibit weekly oscillatory zoning with high $\mathrm{Th} / \mathrm{U}$ ratios (0.39-1.42) and are generally corroded by the grey mantle or light overgrowth rim. In contrast, mantles have distinct low Th/U ratios $(<0.01)$ and are truncated towards high $\mathrm{Th} / \mathrm{U}$ ratio $(0.24-0.54)$ rims in some cases. Three spot analyses from zircon igneous cores yield a mean weighted average ${ }^{206} \mathrm{~Pb} /{ }^{238} \mathrm{U}$ age of $797 \pm 5 \mathrm{Ma}$ (MSWD $=0.95$ ). Two mantle analytical spots define concordant ${ }^{206} \mathrm{~Pb} /{ }^{238} \mathrm{U}$ ages of $207 \pm 4$ and $209 \pm 1$ Ma with a weighted mean age of $209 \pm 2 \mathrm{Ma}(\mathrm{MSWD}=0.24$ ), while seven spots on zircon rims yield weighted mean ages of $127 \pm 2 \mathrm{Ma}$ $(\mathrm{MSWD}=1.7$ ) (Figure 9a). Analytical spots on zircons from 1310YZH1-1 yield similar weight mean ${ }^{206} \mathrm{~Pb} /{ }^{238} \mathrm{U}$ ages: $802 \pm 10 \mathrm{Ma}(\mathrm{MSWD}=3.0, n=4)$ for igneous cores, $233 \pm 3 \mathrm{Ma}(\mathrm{MSWD}=0.077, n=2)$ for metamorphic mantles and $131 \pm 1 \mathrm{Ma}(\mathrm{MSWD}=1.02, n=8)$ for rims, respectively (Figure 9b). Thus, zircon igneous cores indicate the ages of protolith which are Neoproterozoic ( 800 Ma).
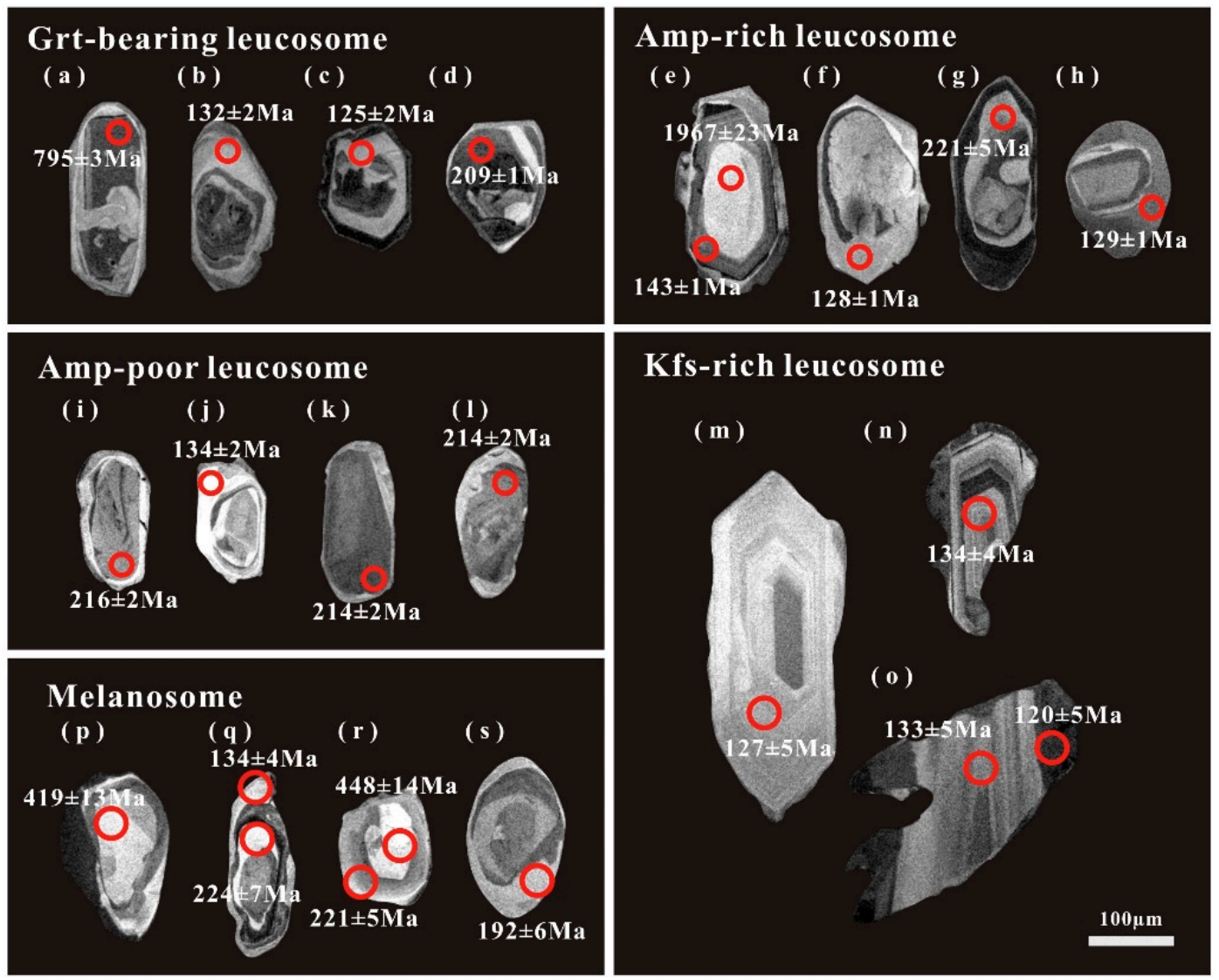

Figure 8. Cathodoluminescence images of zircons in various leucosomes and melanosomes in the NDZ. (a-d) zircons in Grt-bearing leucosomes; (e-h) zircons in Amp-rich leucosomes; (i-1) zircons in Amp-rich leucosomes; (m-o) zircons in Kfs-rich leucosomes; (p-s) zircons in melanosomes. Zircons (a-l) were analyzed on the SHRIMP with a $24-\mu \mathrm{m}$ beam; zircons (m-s) were measured on LA-ICPMS with a $32-\mu \mathrm{m}$ beam. The red open circles are analysis spots with available ${ }^{206} \mathrm{~Pb} /{ }^{238} \mathrm{U}$ ages. 

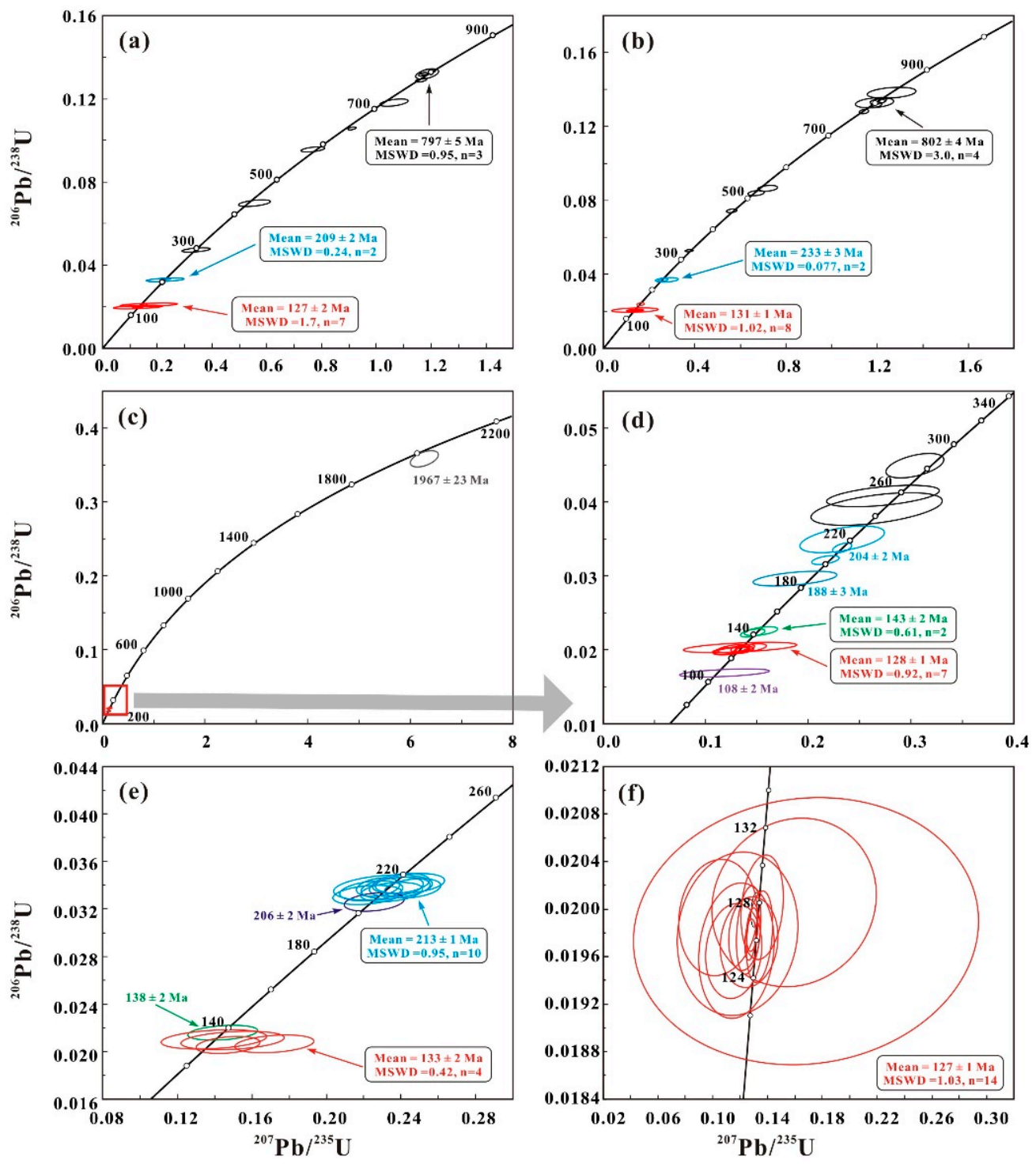

Figure 9. Zircon SHRIMP U-Pb dating of Grt-bearing, Amp-rich and -poor leucosomes in the NDZ. (a) Grt-bearing leucosome (sample 1310YZH6-1); (b) Grt-bearing leucosome (sample 1310YZH1-1); (c,d) Amp-rich leucosome (sample 11410BJ1-4); (e) Amp-poor leucosome (sample 1410BJ1-1); (f) Amp-poor leucosome (sample 1310YZH6-3). Size of uncertainty envelopes is 2 sigma. Different colors of curves indicate that they were dated from different zircon domains as mentioned in the text.

The zircons from Amp-rich leucosomes (sample 1410BJ1-4) are subhedral to anhedral, prismatic to equant and translucent. Most zircons exhibit core-mantle-rim structure in CL images with grain sizes ranging from 100 to $200 \mu \mathrm{m}$. Weekly zoned cores occasionally occur in several zircon grains and are generally corroded at the grey mantles (Figure $8 \mathrm{e}-\mathrm{h}$ ). Seven analytical spots of zircons from outer light rims with high $\mathrm{Th} / \mathrm{U}$ ratios (0.11-0.19) and two spots of inner grey rims with low $\mathrm{Th} / \mathrm{U}$ ratios $(0.05-0.14)$ define weighted mean ages of $128 \pm 1 \mathrm{Ma}(\mathrm{MSWD}=0.92)$ and $143 \pm 2 \mathrm{Ma}(\mathrm{MSWD}=0.61$ ), respectively (Figure 9d). Four spots analyses on the grey mantles yield ${ }^{206} \mathrm{~Pb} /{ }^{238} \mathrm{U}$ ages from $220 \pm 5 \mathrm{Ma}$ to $188 \pm 3 \mathrm{Ma}$ with low $\mathrm{Th} / \mathrm{U}$ ratios ranging from 0.01 to 0.15 , which is consistent with the time of Triassic peak and retrograde metamorphism. Three zircon cores have discordant ${ }^{206} \mathrm{~Pb} /{ }^{238} \mathrm{U}$ ages from $247 \pm 6 \mathrm{Ma}$ to $283 \pm 4 \mathrm{Ma}$ with ${ }^{206} \mathrm{Pbc}$ ranging from 0.35 to $0.66 \%$, which may be related to recent Pb-loss (Figure 9d). The oldest age of $1967 \pm 23 \mathrm{Ma}$ (Figure 9c) was obtained for an unzoned inherited core in CL image (Figure 8e), while the youngest age of $108 \pm 2$ Ma was obtained for a grey outer overgrowth rim (Figure 9d). 
Zircons from Amp-poor leucosomes (sample 1410BJ1-1 and 1310YZH6-3) are colorless, subhedral and transparent. Most of the grains are prismatic and exhibit core-rim textures with aspect ratios of $\sim 2: 1$ and length ranging from 100 to $200 \mu \mathrm{m}$ (Figure 8i-1). Ten analytical spots of zircon cores $(\mathrm{Th} / \mathrm{U}<0.11)$ from sample $1410 \mathrm{BJ} 1-1$ yield ${ }^{206} \mathrm{~Pb} /{ }^{238} \mathrm{U}$ ages with a weighted mean of $213 \pm 1 \mathrm{Ma}(\mathrm{MSWD}=0.95)$ while one grey core $(\mathrm{Th} / \mathrm{U}=0.11)$ defines a younger age of $206 \pm 2 \mathrm{Ma}$ (Figure 9e). Four spot analyses of outer rims $(\mathrm{Th} / \mathrm{U}=0.57-0.71)$ reveal a weighted mean age of $133 \pm 2 \mathrm{Ma}(\mathrm{MSWD}=0.42)$ and one spot on an inner grey $\mathrm{rim}(\mathrm{Th} / \mathrm{U}=0.06)$ yields an older age of $138 \pm 2 \mathrm{Ma}$ (Figure 9e). In contrast, no Triassic ages were detected from the zircon core domains in sample 1310YZH6-3. Fourteen analytical spots of zircons in this sample define a weighted mean ${ }^{206} \mathrm{~Pb} /{ }^{238} \mathrm{U}$ age of $127 \pm 1 \mathrm{Ma}$ (MSWD $=1.03$ ) (Figure 9f).

Zircons from Kfs-rich leucosomes (samples 1310YZH2-2 and 1310YZH 7-4) are colorless, euhedral, prismatic and transparent; most of the grains are larger with length up to $500 \mu \mathrm{m}$ as compared to zircons from other groups of leucosomes. Several zircons in sample 1310YZH2-2 exhibit core-mantle-rim texture in the CL images (Figure $8 \mathrm{~m}-\mathrm{o}$ ) and three distinct ages were obtained from this sample (Figure 10a). The oldest group is represented by distinct oscillatory grey core domains with twelve analytical spots, which defined a weighted ${ }^{206} \mathrm{~Pb} /{ }^{238} \mathrm{U}$ age of $133 \pm 3 \mathrm{Ma}(\mathrm{MSWD}=0.34)$. The second group of weakly zoned light-colored mantle domains gave nine analyses with concordant ages and a mean of $124 \pm 3 \mathrm{Ma}(\mathrm{MSWD}=0.54)$. The youngest group is defined by two analyses of rim domains, having a weighted mean age of $114 \pm 7 \mathrm{Ma}(\mathrm{MSWD}=0.08)$ (Figure 10a). On the other hand, analyses on zircon cores, mantles and rims from sample $1310 Y Z H 7-4$ reveal coincident ${ }^{206} \mathrm{~Pb} /{ }^{238} \mathrm{U}$ ages with weighted mean ages of $134 \pm 3 \mathrm{Ma}(\mathrm{MSWD}=0.51, n=7), 124 \pm 2 \mathrm{Ma}(\mathrm{MSWD}=0.46, n=12)$ and $114 \pm 3$ Ma (MSWD $=0.68, n=6)$, respectively (Figure 10b).

Zircons from the NDZ melanocratic migmatites (samples 1410BJ1-2, 1410LTSP1 and 1410MSH2-1) are colorless, transparent, irregular, subhedral to anhedral with length up to $200 \mu \mathrm{m}$. Zircons from sample 1410BJ1-2 exhibit typical zoning texture with grey cores, dark mantles and grey rims while some of the grains lacking clear cores and/or rims in CL images (Figure 8p-s). Minor zircons cores exhibit oscillatory structure while most are homogeneous. Three spot analyses on oscillatory cores yield discordant Pb-loss ages of $419 \pm 13 \mathrm{Ma}, 448 \pm 14 \mathrm{Ma}$ and $425 \pm 15 \mathrm{Ma}$ with $\mathrm{Th} / \mathrm{U}$ ratios ranging from 0.41 to 1.35 . Nineteen spots of zircon mantles with low $\mathrm{Th} / \mathrm{U}$ ratios reveal ${ }^{206} \mathrm{~Pb} /{ }^{238} \mathrm{U}$ ages ranging from $167 \pm 6 \mathrm{Ma}$ to $225 \pm 7 \mathrm{Ma}$ related to the Triassic peak and retrograde metamorphism. The metamorphic zircon mantle can be subdivided to four domains based on the CL zoning and Th/U ratios, with weight mean ages of $223 \pm 6 \mathrm{Ma}(\mathrm{MSWD}=0.09, n=4), 207 \pm 5 \mathrm{Ma}(\mathrm{MSWD}=0.24, n=5)$, $191 \pm 5$ Ma $($ MSWD $=0.19, n=6)$ and $171 \pm 7$ Ma (MSWD $=0.68, n=6)$, respectively (Figure 10c). The grey rim domains are very thin and one spot yield a concordant ${ }^{206} \mathrm{~Pb} /{ }^{238} \mathrm{U}$ age of $134 \pm 4 \mathrm{Ma}$ with Th/U ratio of 0.23 (Figure 10c). In contrast, zircons from 1410LTSP1 exhibit core-rim texture with oscillatory cores and grey rims. However, the rim domains are generally too thin to be analyzed. Eleven spot analyses of zircon cores define two distinct age groups with weight mean ${ }^{206} \mathrm{~Pb} /{ }^{238} \mathrm{U}$ ages of $787 \pm 27 \mathrm{Ma}(\mathrm{MSWD}=0.21, n=4)$ and $715 \pm 19 \mathrm{Ma}(\mathrm{MSWD}=0.16, n=7)$. One grey rim in this sample defines a younger age of $117 \pm 7 \mathrm{Ma}$ (Figure 10d). Moreover, zircon grains from sample 1410MSH2-1 also display core-mantle-rim texture with magmatic cores (rarely preserved) and thin rims. Mantles can be subdivided into three zones (M1, M2 and M3) from the interior to the exterior based on the CL characters, with the majority of M1 zones showing oscillatory zoning. Analytical spots of M1, M2 and M3 domains yield weight mean ${ }^{206} \mathrm{~Pb} /{ }^{238} \mathrm{U}$ ages of $136 \pm 6 \mathrm{Ma}(\mathrm{MSWD}=0.39, n=2), 126 \pm 2 \mathrm{Ma}$ $(\mathrm{MSWD}=0.58, n=10)$ and $117 \pm 4 \mathrm{Ma}(\mathrm{MSWD}=0.65, n=4)$, respectively (Figure 10f). One spot from a light grey unzoned core with low $\mathrm{Th} / \mathrm{U}$ ratio yields a ${ }^{206} \mathrm{~Pb} /{ }^{238} \mathrm{U}$ age of $217 \pm 12 \mathrm{Ma}$ while five spot analyses of zoned cores preserve discordant ages ranging from $544 \pm 19 \mathrm{Ma}$ to $359 \pm 10 \mathrm{Ma}$ with higher Th/U ratios (Figure 10e). One analytical spot of rim defines a younger ${ }^{206} \mathrm{~Pb} /{ }^{238} \mathrm{U}$ age of $109 \pm 3$ Ma (Figure 10f). 

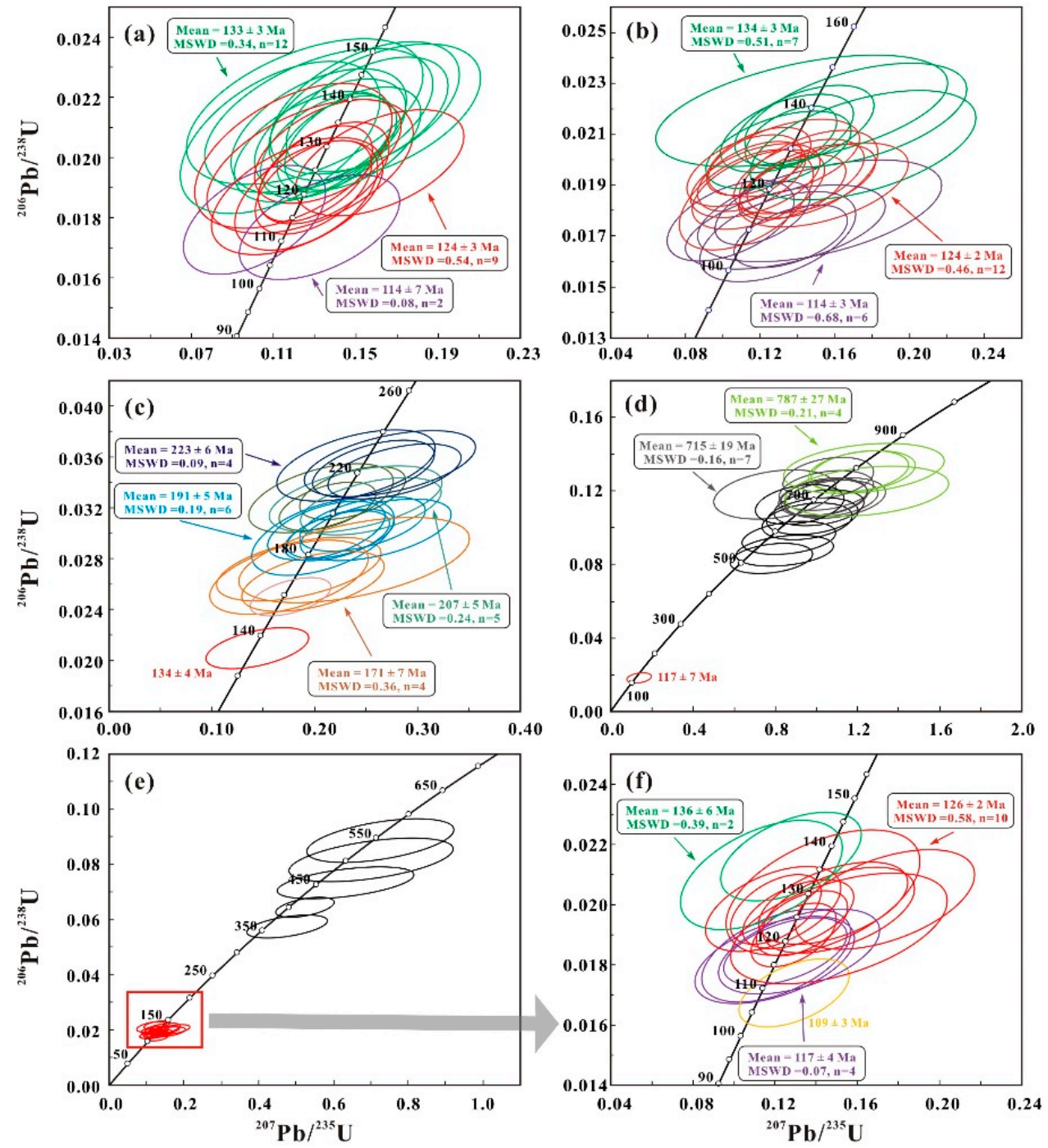

Figure 10. Zircon LA-ICPMS U-Pb dating of Kfs-rich leucosomes and melanocratic migmatites in the NDZ. (a) Kfs-rich leucosome (sample 1310YZH2-2); (b) Kfs-rich leucosome (sample 1310YZH7-4); (c) melanocratic migmatite (sample 1410BJ1-2); (d) melanocratic migmatite (sample 1410LTSP1); (e,f) melanocratic migmatite (sample 1410MSH2-1). Size of uncertainty envelopes is 2 sigma. Different colors of curves indicate that they were dated from different zircon domains as mentioned in the text.

\subsection{Whole-Rock $\mathrm{Rb}-\mathrm{Sr}, \mathrm{Sm}-\mathrm{Nd}$ and $\mathrm{Pb}$ Isotopes}

Whole-rock $\mathrm{Rb}-\mathrm{Sr}, \mathrm{Sm}-\mathrm{Nd}$ and $\mathrm{Pb}$ isotopic compositions of the melanosomes and the four groups of leucosomes are listed in Supplementary Table S4 and illustrated in Figures 11 and 12. Initial Sr, $\mathrm{Nd}$ and $\mathrm{Pb}$ isotope ratios are calculated back to $130 \mathrm{Ma}$. This age was interpreted as the formation peak-age of the NDZ migmatites [34,35]. Most leucosomes exhibit relatively variable $\mathrm{Rb}-\mathrm{Sr}$ isotopic compositions with negative $\varepsilon_{N d}(t)$ values ranging from -24.76 to -6.47 and initial ${ }^{87} \mathrm{Sr} /{ }^{86} \mathrm{Sr}$ ratios varying from 0.7063 to 0.7144 (Figure 11a). One Grt-bearing leucosome sample (1310YZH1-1) falls outside the main set with a higher initial ${ }^{87} \mathrm{Sr} /{ }^{86} \mathrm{Sr}$ ratio of 0.7196 . Melanosome and migmatite samples have similar Sr-Nd isotopic compositions with those of the leucosomes. In addition, both initial ${ }^{87} \mathrm{Sr} /{ }^{86} \mathrm{Sr}$ and ${ }^{143} \mathrm{Nd} /{ }^{144} \mathrm{Nd}$ ratios exhibit no distinct correlation with the whole-rock $\mathrm{SiO}_{2}$ contents (Figure $11 \mathrm{~b}, \mathrm{c}$ ). 

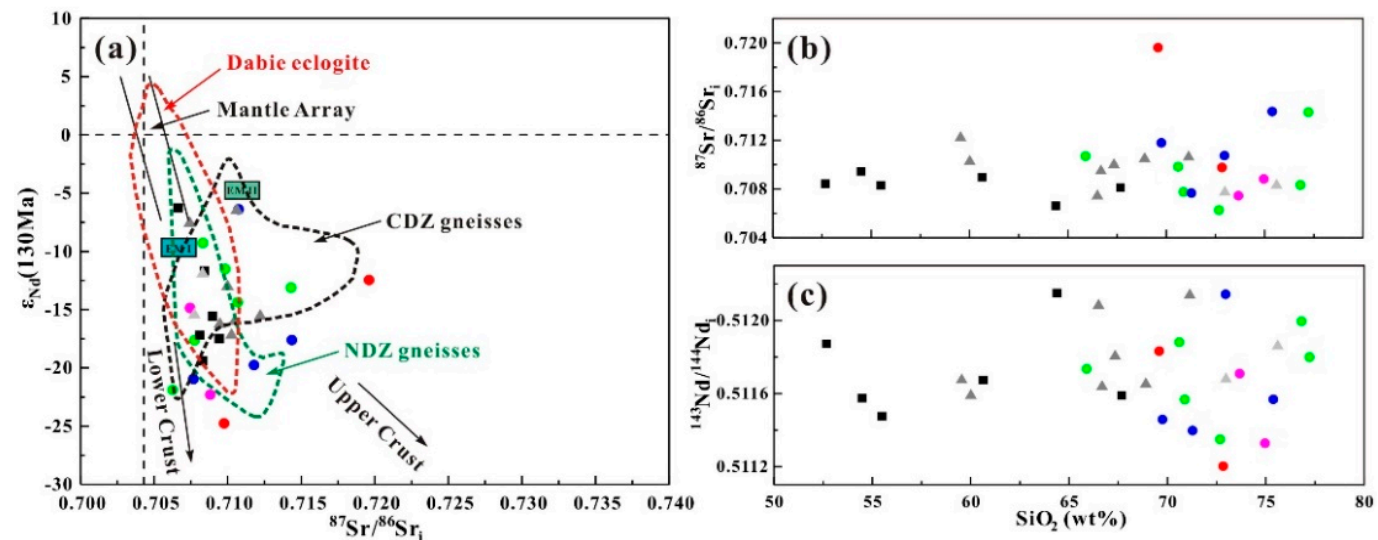

Figure 11. Sr-Nd isotopic scatter diagram of various leucosomes and melanosomes of migmatites in the NDZ. (a) ${ }^{87} \mathrm{Sr} /{ }^{86} \mathrm{Sr}_{\mathrm{i}}$ vs. $\varepsilon_{\mathrm{Nd}}\left(130 \mathrm{Ma}\right.$ ) diagram; (b) $\mathrm{SiO}_{2}$ (wt.\%) vs. ${ }^{87} \mathrm{Sr} /{ }^{86} \mathrm{Sr}_{\mathrm{i}}$ diagram; (c) $\mathrm{SiO}_{2}$ vs. ${ }^{143} \mathrm{Nd} /{ }^{144} \mathrm{Nd}_{\mathrm{i}}$ diagram. Representative data for the CDZ gneisses, NDZ gneisses and Dabie eclogites are from [72]). The Sr-Nd isotopic compositions of EMI and EMII are from [73]. The arrows point to lower and upper crust, respectively. Other symbols are the same as in Figure 5.
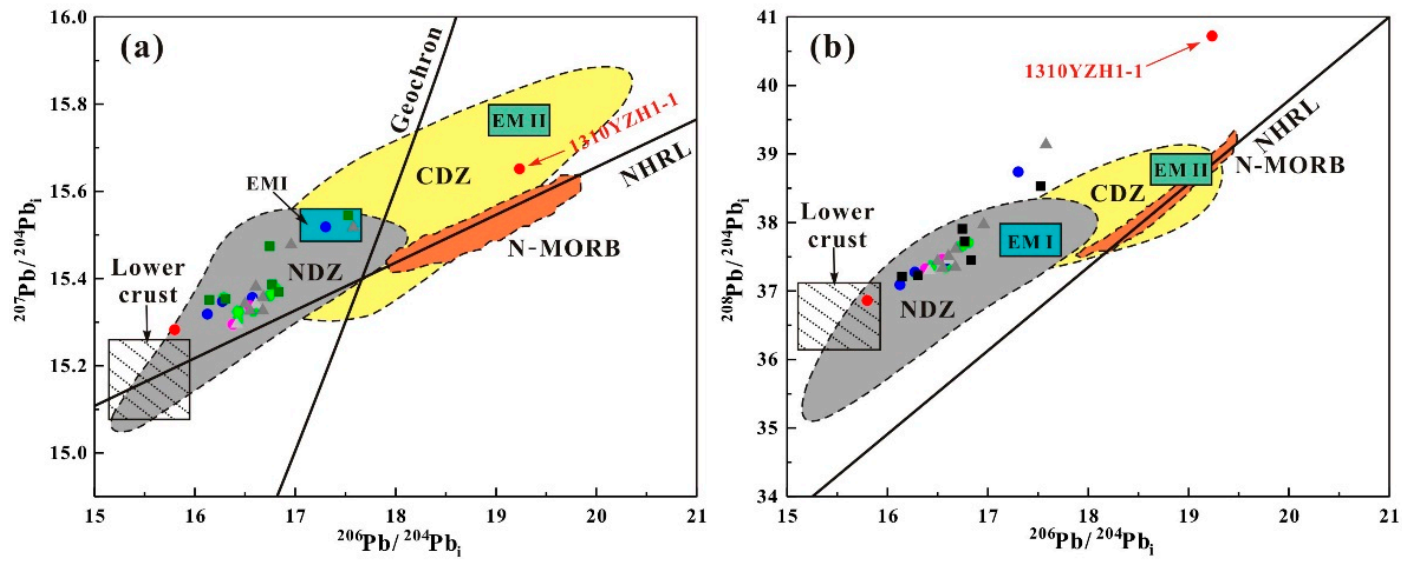

Figure 12. Plots of ${ }^{206} \mathrm{~Pb} /{ }^{204} \mathrm{~Pb}$ vs. ${ }^{207} \mathrm{~Pb} /{ }^{204} \mathrm{~Pb}(\mathbf{a})$ and ${ }^{206} \mathrm{~Pb} /{ }^{204} \mathrm{~Pb}$ vs. ${ }^{208} \mathrm{~Pb} /{ }^{204} \mathrm{~Pb}(\mathbf{b})(\mathrm{t}=130 \mathrm{Ma})$ for various leucosomes and melanosomes of migmatites in the NDZ. The grey and yellow fields represent data for the UHP orthogneisses and eclogites from the NDZ and CDZ, respectively (modified from [45]). Other symbols are the same as in Figure 5.

Amp-rich, Amp-poor and Kfs-rich leucosomes have uniform initial ${ }^{206} \mathrm{~Pb} /{ }^{204} \mathrm{~Pb},{ }^{207} \mathrm{~Pb} /{ }^{204} \mathrm{~Pb}$ and ${ }^{208} \mathrm{~Pb} /{ }^{204} \mathrm{~Pb}$ ratios ranging between $16.1245-16.8017,15.2957-15.3775$ and 37.0906-37.7080, respectively, and plot in the NDZ eclogite field except for one Amp-poor leucosome sample (1410LTSP2) with slightly higher initial $\mathrm{Pb}$ isotopic ratios (Figure 12). Two samples of Grt-bearing leucosomes, however, exhibit remarkably inhomogeneous Pb isotopic characters. Sample 1310YZH1-1 have the highest initial ${ }^{206} \mathrm{~Pb} /{ }^{204} \mathrm{~Pb},{ }^{207} \mathrm{~Pb} /{ }^{204} \mathrm{~Pb}$ and ${ }^{208} \mathrm{~Pb} /{ }^{204} \mathrm{~Pb}$ ratios $(19.2345,15.6516$ and 40.7216 , respectively) while 1310YZH6-1 exhibits the lowest $\mathrm{Pb}$ isotopic ratios (15.7984, 15.2828 and 36.8614 , respectively) among all types of samples.

\section{Discussion}

\subsection{Mechanism of Anatexis for the Different Generations of Leucosomes}

The four groups of leucosomes identified within the migmatites of the NDZ have different mineral assemblages and compositions, probably indicating a complex anatectic evolution potentially over a significant time period (late Triassic to early Cretaceous). In addition, the NDZ underwent multiple metamorphic stages during subduction, exhumation and mountain-root collapse with respective changes in physico-chemical parameters such as pressure, temperature, fluid and melt. Thus, in order 
to understand this complex history, it is important to clarify the mechanism of anatexis and the genesis of each type of leucosome in the region.

\subsubsection{Fluid-Absent Decompression Melting}

Continental crustal rocks are generally devoid of free water, especially in the middle and lower structural levels, as a result of the high pressure and low porosity. In spite of the fact that fluid-present partial melting could take place in several specific environments such as shear zones [74], fluid-absent anatexis is still the main mechanism of deep continental crust anatexis under most conditions $[75,76]$. However, mica-dehydration melting has been invoked as frequent mechanism in the deep crust anatexis [77]. It is well established that the NDZ was involved in the deep subduction and went through UHP metamorphism in the Triassic [28,29,47,48,58]. Moreover, detailed petrological and geochronological investigations documented that the NDZ experienced a rapid early stage of exhumation, followed by a comparatively slower exhumation rate at high-T conditions $[30,41,42,49,52]$. Rapid decompression of the subducted slab coupled with approximately constant high temperature took place on the early stage of the NDZ terrane exhumation, providing a precondition for partial melting of the NDZ lithologies thanks to hydrous minerals (such as biotite) breaking down and releasing free water.

As mentioned above, the Grt-bearing leucosomes provide clues to explore evidence for a set of older anatexis of the NDZ before the Cretaceous mountain-root collapse. In the field, Grt-bearing leucosomes are relatively rare in the NDZ and volumetrically minor, generally displaying enclosed in situ patches or intensely deformed thin leucocratic veins (Figure $3 \mathrm{a}-\mathrm{c}$ ). Garnets dispersed in the leucosomes are proven to be peritectic based on their porphyroblastic and poikilitic habit, peculiar compositional zoning and occurrence of multiphase inclusions of $\mathrm{Qz}+\mathrm{Pl}( \pm \mathrm{Chl}$ ) (Figure $4 \mathrm{a}-\mathrm{f})$. The EMP analysis suggests garnets therein have compositional zoning with spessartite increasing and almandine decreasing from core to rim (Supplementary Table S5), indicating that garnets grew in equilibrium with anatectic melt [77-80]. Because garnet is an anhydrous mineral and does not occur in other leucosomes, the mechanism of formation of the Grt-bearing leucosomes might be significantly different, specifically concerning the $\mathrm{H}_{2} \mathrm{O}$ activity. However, deformed Grt-bearing leucosomes are generally cross cut by undeformed Amp-rich, Amp-poor or Kfs-rich leucosomes, suggesting that the Grt-bearing leucosomes could have been involved and consequently modified by Cretaceous anatexis. Modification is also supported by 127-131 Ma zircon records in the samples 1310YZH6-1 and 1310YZH1-1 (Figure 9a,b). Re-equilibration of minerals and melts mixing during the Cretaceous anatectic event hampers one's ability to precisely constrain the evolution of the Grt-bearing leucosomes. Nevertheless, the P-T conditions at which the Grt-bearing leucosomes were formed, were tentatively constrained by combining whole-rock zircon saturation thermometry [81] and hornblende-garnet-plagioclase barometry [82], which give P-T conditions of $872-941^{\circ} \mathrm{C}$ and $8.2-10.0 \mathrm{kbar}$, i.e., higher $\mathrm{T}$ and $\mathrm{P}$ than biotite dehydration-melting solidus $[83,84]$. The observed low melt volumes and the estimated high temperature of the melts are consistent with the hypothesis that anatexis was preferentially driven by dehydration melting of biotite under fluid-absent conditions.

High whole-rock $\mathrm{Rb} / \mathrm{Sr}$ (with average of 0.36 ) and $\mathrm{Rb} / \mathrm{Ba}$ ratios of Grt-bearing leucosomes (Figure 13a) indicate that biotite consumption likely played an important role during this partial melting event. The negative Eu anomalies with $\delta_{\mathrm{Eu}}$ ranging from 0.25 to 0.37 , support the absence of plagioclase during anatexis and are consistent with elements behavior in fluid-absent partial melting [85]. The Grt-bearing leucosome could have formed through biotite dehydration melting according to the following reaction:

$$
\text { Biotite }+ \text { Quartz }+ \text { Epidote } \rightarrow \text { Garnet }+ \text { Amphibole }+ \text { Orthoclase }+ \text { Plagioclase }+ \text { melt }
$$



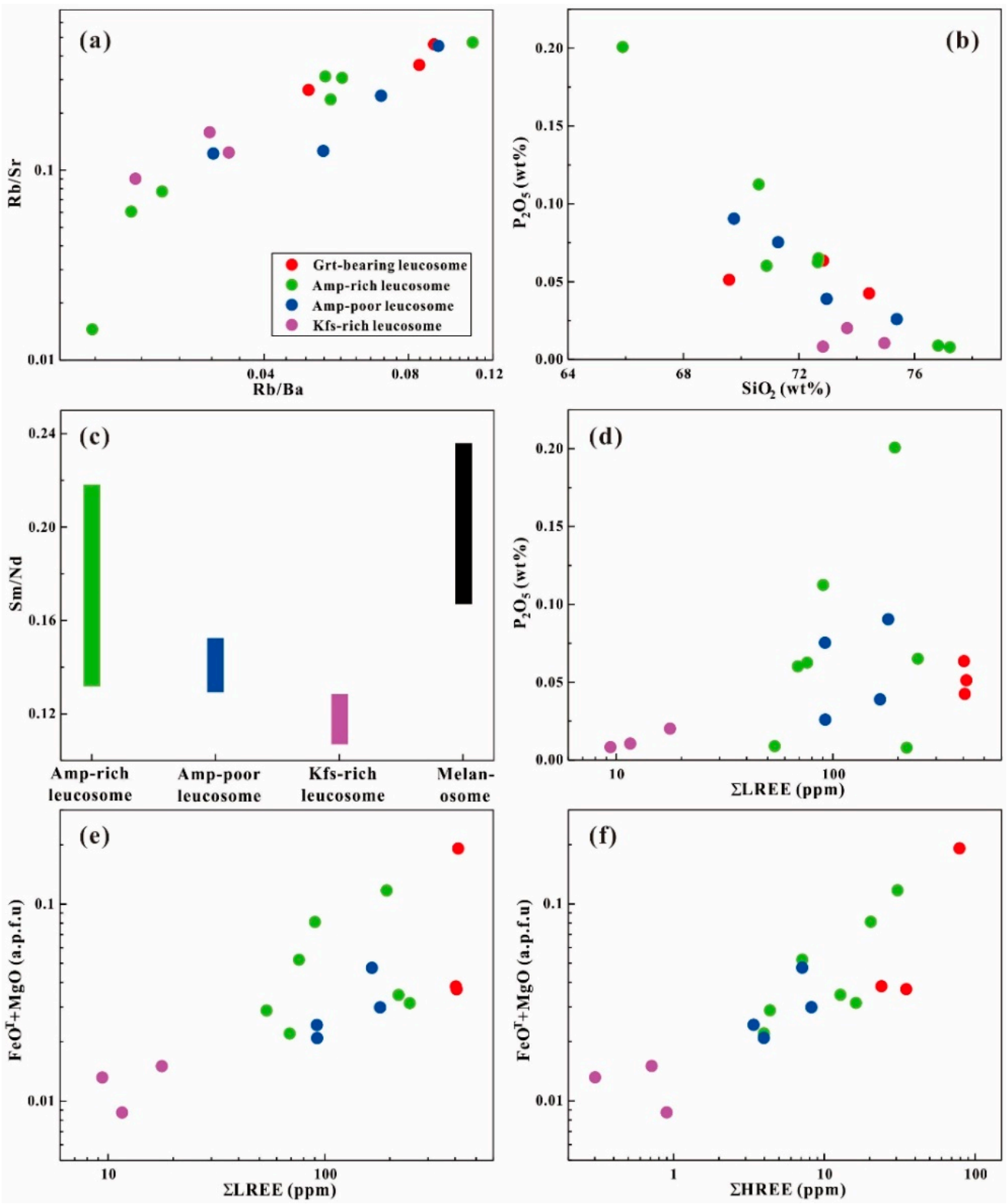

Figure 13. Binary plots of major and trace element compositions for various leucosomes and melanosomes of migmatites in the NDZ. (a) $\mathrm{Rb} / \mathrm{Ba}$ vs. $\mathrm{Rb} / \mathrm{Sr}$ diagram; (b) $\mathrm{SiO}_{2}$ vs. $\mathrm{P}_{2} \mathrm{O}_{5}$ diagram; (c) $\mathrm{Sm} / \mathrm{Nd}$ ratios of leucosomes and melanosomes; (d) $\Sigma$ LREE vs. $\mathrm{P}_{2} \mathrm{O}_{5}$ diagram; (e) $\Sigma$ LREE vs. $\mathrm{FeO}_{\mathrm{T}}+\mathrm{MgO}$ diagram; (f) $\Sigma$ HREE vs. $\mathrm{FeO}_{\mathrm{T}}+\mathrm{MgO}$ diagram.

The consumption of biotite during decompression released small amounts of aqueous fluid into the rock and produced low volumes of melt. Garnets, being a peritectic anhydrous phase, exclude the possibility of abundant external fluid injection. However, water would partially or even completely alter anhydrous minerals in the proximity of leucosomes [61,86].

\subsubsection{Fluid-Fluxed Melting}

Melting triggered by influx of a free aqueous fluid has commonly been inferred as a widespread process in the continental collision zones [87-89]. This is particularly true at low temperatures, since $\mathrm{H}_{2} \mathrm{O}$ is strongly enriched in the silicate melt rather than the residuum and would therefore reduce the Gibbs free energy of the system [90,91]. In the Amp-rich, Amp-poor and Kfs-rich leucosomes, the absence of anhydrous peritectic minerals reduces the possibility that these leucosomes were formed through fluid-absent anatexis. Moreover, the occurrence of amphibole as peritectic mineral in Amp-rich 
leucosomes, as testified by its coarse-grained, euhedral and poikilitic habit, as well as by the rounded inclusions of biotite, plagioclase and quartz (Figure 3d) [61,85,88], suggests these leucosomes were formed under high fluid-flux conditions, because at least $2-4$ wt. $\% \mathrm{H}_{2} \mathrm{O}$ are required to stabilize amphibole above the water-saturated solidus [92,93].

Under fluid-absent conditions, amphibole can be in principle produced by dehydration melting of biotite through reactions like $\mathrm{Bt}+\mathrm{Qz}+\mathrm{Ep}=\mathrm{Amp}+\mathrm{Grt}+\mathrm{Or}+\mathrm{Pl}+$ melt [94]. However, partial melting of crustal rocks triggered by this mechanism would generally produce small amounts of melts (limited by the volume of all 3 reactant phases, but most likely by biotite), lower than 5 vol\% under amphibolite-facies conditions [83,95], which is inconsistent with the great melt volumes observed in the NDZ (Figure 3d-f). Therefore, biotite dehydration melting under fluid-absent conditions cannot have been the dominating mechanism of the early Cretaceous anatexis. In addition, Amp-rich leucosomes are generally surrounded by dark rims consisting almost exclusively of mafic minerals (amphiboles and biotites), indicating that hydrous minerals were not decomposed during anatexis [87,96,97].

Biotite is the critical mineral concerning $\mathrm{Rb}$ because it takes in this element readily [98], while plagioclase is enriched in $\mathrm{Sr}$ and $\mathrm{Ba}$ [99]. Therefore, biotite vs. plagioclase consumption during fluid-absent vs. fluid-present partial melting can significantly affect the trace element contents in melts [100]. Amp-rich, Amp-poor and Kfs-rich leucosomes display low Rb/Sr ratios with averages of $0.21,0.23$ and 0.12 , respectively. $\mathrm{Rb} /$ Ba ratios of three types of leucosomes also exhibit similar lower values relative to the Grt-bearing leucosomes (Figure 13a), indicating that plagioclase consumption during fluid-present partial melting played the dominant role during the Cretaceous anatectic event. The absence of Eu anomalies in Amp-rich and -poor leucosomes and the pronounced positive Eu anomalies in Kfs-rich leucosomes (Figure 6c,e,g) are also in agreement with the hypothesis of external fluid influx during anatexis [85].

Fluid-fluxed partial melting triggered by the following reaction [25,89] is consistent with the occurrence of biotite, plagioclase and quartz inclusions in peritectic amphibole (Figure 3i,j):

$$
\text { Biotite }+ \text { Plagioclase }+ \text { Quartz }+ \text { water } \rightarrow \text { Amphibole }+ \text { quartz-feldspathic melt }
$$

Al-in-amphibole barometry applied to rocks with mineral assemblage of Amp $+\mathrm{Bt}+\mathrm{Pl}+\mathrm{Or}$ $+\mathrm{Qz}+\mathrm{Ttn}+\mathrm{Mag}$ (Ilm) [101] can be used to determine the pressures during stromatic migmatites formation. Combining this method with the amphibole-plagioclase thermometer of [102], the P-T conditions of Amp-rich leucosomes formation are found to be in the range $2.3-4.4 \mathrm{kbar}$ and $665-789^{\circ} \mathrm{C}$ combining peritectic amphibole compositions together with those of its rounded plagioclase inclusions. The estimated temperatures are higher than the wet solidus of granitic rocks [103], but significantly lower than the biotite dehydration-melting solidus [83,84]. Thus, fluid-flux melting is inferred to have been the dominant mechanism of the widespread anatexis and migmatization during the Cretaceous in the NDZ.

\subsection{Ages of the Different Generations of Leucosomes}

As mentioned above, the NDZ terrane underwent multiple anatexis stages triggered by different mechanisms during both the initial stage of the exhumation and post-orogenic mountain-root collapse; that is, the late Triassic and early Cretaceous as previously suggested by [41] based on the investigation of eclogites. Geochronological data reported in this study show that zircons from the different generations of leucosomes retain complex age records related to the NDZ evolution. More specifically, zircons in the studied samples reveal multiple-age spectra related to leucosome crystallization and corresponding precursor igneous and metamorphic stages, and their subsequent overprinting of thermal events.

Zircons in Grt-bearing leucosomes retain Neoproterozoic inherited magmatic cores with an average mean age of $797 \pm 5 \mathrm{Ma}$ (Figures $8 \mathrm{a}-\mathrm{d}$ and $9 \mathrm{a}, \mathrm{b}$ ), consistent with the age of one episode of granites emplacement at the northern margin of the South China Block during Rodinia supercontinent 
breakup [29,31,104]. Analyses of two zircon mantles define ${ }^{206} \mathrm{~Pb} /{ }^{238} \mathrm{U}$ ages of $207 \pm 4$ and $209 \pm 1 \mathrm{Ma}$ with a weighted mean of $209 \pm 2 \mathrm{Ma}$; these mantles replace inherited cores exhibiting embayed and corroded structures and relatively high $\mathrm{U}$ content $(808 \mathrm{ppm})$, and are therefore interpreted as derived from zircon overgrowth in anatectic melts, rather than from metamorphic recrystallization [105-107]. The zircon mantle ages are also comparable with the ages of the UHT granulite-facies overprinting of the subducted NDZ terrane (207 $\pm 4 \mathrm{Ma}$; [30]) within error, and with the timing of one episode of partial melting for the eclogites in this region [30,41]. Therefore, combined with field occurrence (Figure $3 a-c$ ) and mineral assemblages (Figure 4), the U-Pb ages of $209 \pm 2$ Ma likely represent the crystallization age of Grt-bearing leucosomes during the Triassic fluid-absent decompression melting. Zircon cores and mantles are generally truncated by light-colored rims with high $\mathrm{Th} / \mathrm{U}$ ratios, which yield a weighted mean age of $127 \pm 2 \mathrm{Ma}$. This younger age is interpreted as related to thermal overprinting of the Grt-bearing leucosomes during the Cretaceous large-scale anatexis and migmatization occurred at ca. $127 \mathrm{Ma}$.

Zircons in Amp-rich leucosomes also retain clues of a complex evolution (Figures 8 and 9c,d). One homogenous inherited core, three zoned cores and four grey mantles yield ages of $1967 \pm 23 \mathrm{Ma}$, 247-283 Ma and 220-188 Ma, respectively, corresponding to the Paleoproterozoic metamorphism, Neoproterozoic magmatism ( $\mathrm{Pb}$ loss) and Triassic-Jurassic multistage metamorphism. Two populations of zircon rims from Amp-rich leucosomes define weighted mean ages of $143 \pm 2 \mathrm{Ma}$ with low Th/U ratios of $0.05-0.14$, and $128 \pm 1 \mathrm{Ma}$ with relatively high $\mathrm{Th} / \mathrm{U}$ ratios ranging from 0.11 to 0.19 . Since zircons with low $\mathrm{Th} / \mathrm{U}$ ratios represent the initial crystallization — whereas those with high $\mathrm{Th} / \mathrm{U}$ ratios generally record later precipitation [108] with fluid infiltration [109] — these ages likely represent the earlier crystallization stage under higher temperature and the later crystallization stage at wet solidus, respectively. In addition, one mantle analytic point defines an age of $204 \pm 2 \mathrm{Ma}$ and shows high $\mathrm{U}$ content (1374 ppm), suggestive of its growth from an anatectic melt [105-107]. This age would correspond to one episode of partial melting, which is similar to those from the Grt-bearing leucosomes (Figure 9a). However, another analytic point on the metamorphic mantle domain with grey CL image (Figure 8) gives $221 \pm 5 \mathrm{Ma}$ and shows a low Th/U ratio of 0.01 , consistent with its metamorphic origin [107] and similar to the timing of eclogite-facies metamorphism found in the eclogites of the NDZ [58].

Amp-poor leucosomes show slight differences between the two studied samples. In addition to the cores recording Triassic ages ranging from 218 to $206 \mathrm{Ma}$, zircons from sample 1410BJ1-1 record two weighted mean ages of $138 \pm 2$ and $133 \pm 2$ Ma based on the Th/U ratio and morphological features. In sample 1310YZH6-3, 14 zircons yield a weighted mean ${ }^{206} \mathrm{~Pb} /{ }^{238} \mathrm{U}$ age of $127 \pm 1 \mathrm{Ma}$ (Figure 9f). In these regards, the Amp-poor leucosomes crystallized slightly later than the Amp-rich leucosomes.

Kfs-rich leucosomes consist of coarse-grained quartz and plagioclase and minor K-feldspar with accessory minerals. CL images of zircons from this group generally exhibit core-mantle-rim structures (Figure 8) with weighted mean ages of $133 \pm 3,124 \pm 3$ and $117 \pm 7 \mathrm{Ma}$, respectively (Figure 10a,b). Considering that quartz and plagioclase generally crystallize during the last stage of melt evolution at low-temperature conditions, the U-Pb age of $\mathrm{ca} .117 \mathrm{Ma}$ may represent the crystallization stage of the Kfs-rich leucosomes. Besides, the ages of zircon cores and mantles are similar to those of the Amp-rich and -poor leucosomes, and could represent one episode of the earlier crystallization stages.

In summary, the NDZ experienced multiple episodes of anatexis and produced various generations of leucosomes during the Mesozoic continental collision. Low volumes of melts were formed by biotite dehydration melting during the early stage of exhumation in the late Triassic; Grt-bearing leucosomes were formed by in situ crystallization of this melt at $209 \pm 2 \mathrm{Ma}$. At $143 \pm 2 \mathrm{Ma}$, heating and external fluid influx from the country rocks at upper-crustal levels triggered a new episode of anatexis, producing Amp-rich leucosomes with peritectic amphibole. Later, Amp-rich and -poor leucosomes progressively crystallized at decreasing temperature in the age interval 138-124 Ma. Finally, temperatures close to the wet solidus were reached at ca. $117 \mathrm{Ma}$, and Kfs-rich leucosomes crystallized with abundant coarse-grained quartz and plagioclase. Based on these chronological and previously published 
data [30,41,58], combined with the above melting reactions and corresponding P-T conditions for four groups of leucosomes, a P-T-t path was reconstructed in Figure 14.

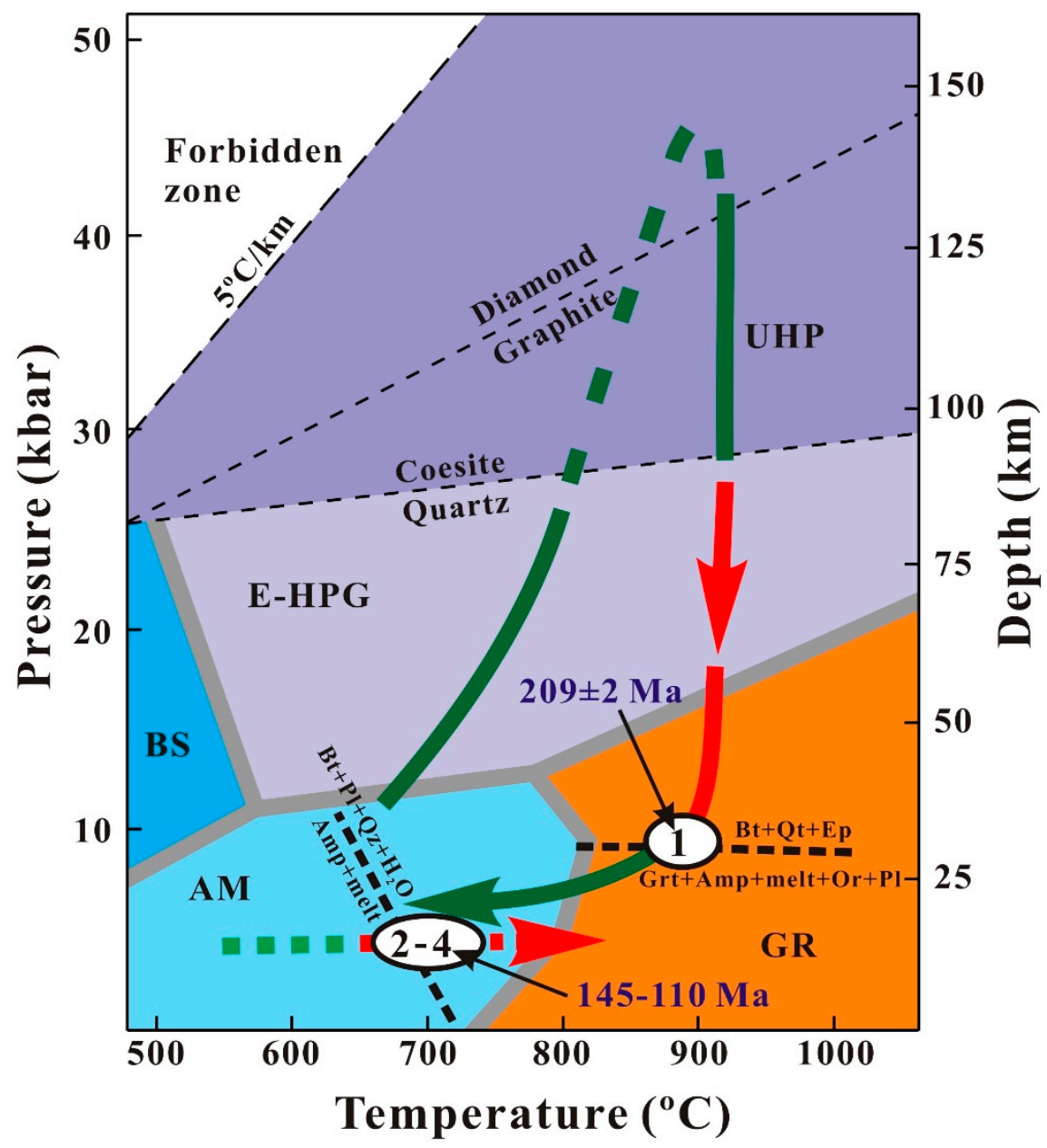

Figure 14. Synthesis of the NDZ P-T-t path (modified from [41]), with emphasis on the two melt-producing reactions occurred during isothermal decompression and heating. The green dashed lines are from [41] and red dashed lines from this study. The black ellipse refers to the P-T conditions estimated for four groups of leucosomes. See the detailed explanations in the text. BS, blueschist-facies; EA, epidote amphibolite-facies; AM, amphibolite-facies; GR, granulite-facies; E-HPG, eclogite-high pressure granulite-facies.

\subsection{Genesis and Elemental-Isotopic Behaviour of Leucosomes.}

The stromatic structure of metatexites is probably the result of overlap from different mechanisms. Some layered migmatites generated from partial melting of strongly layered protoliths [3], while others could formed by repeated injection of melt along parallel planes of weakness during anatexis or be the result of drastic modification of precursor morphology by intense deformation [110-113]. Although the different generations of leucosomes in the NDZ migmatites display different morphologies and mineral assemblages according to their respective mechanisms of anatexis, the results of zircon geochronology and whole-rock $\mathrm{Sr}-\mathrm{Nd}-\mathrm{Pb}$ isotope study (Figures 8-12) suggest they might have similar sources.

Zircons in Grt-bearing, Amp-rich and -poor leucosomes all retain metamorphic-age records of 210-230 Ma with low Th/U ratios; these ages are related to the Triassic deep subduction and subsequent exhumation. Moreover, inherited zircon cores in Grt-bearing and Amp-rich leucosomes, and associated rocks (Figures 9a-c and 10d) preserved records of Neoproterozoic (780-800 Ma) magmatism and Paleoproterozoic $(\sim 2.0 \mathrm{Ga})$ metamorphism as well, providing critical evidence of a source from the South China Block $[114,115]$. It is obvious that the protoliths of different leucosomes experienced 
similar tectonic evolution related to the South China Block and its continental collision towards the North China Block in the Triassic.

Whole-rock Sr-Nd isotopic characters of Grt-bearing leucosomes are consistent with those of the other leucosomes, and ${ }^{87} \mathrm{Sr} /{ }^{86} \mathrm{Sr}$ and ${ }^{143} \mathrm{Nd} /{ }^{144} \mathrm{Nd}$ ratios show no correlation with $\mathrm{SiO}_{2}$ contents (Figure 11), suggesting the rocks did not experience mixing of mantle source materials, while the influence of accessory minerals dissolution such as apatite and monazite were negligible. All samples of leucosomes and melanosomes display low initial ${ }^{87} \mathrm{Sr} /{ }^{86} \mathrm{Sr}$ and ${ }^{143} \mathrm{Nd} /{ }^{144} \mathrm{Nd}$ ratios, meanwhile the two-stage Hf model ages of zircons range from 2.0 to $2.4 \mathrm{Ga}$, indicating the leucosomes were derived from similar protoliths in middle-lower ancient crust. Moreover, the majority of leucosomes and melanosomes display low initial ${ }^{206} \mathrm{~Pb} /{ }^{204} \mathrm{~Pb},{ }^{207} \mathrm{~Pb} /{ }^{204} \mathrm{~Pb}$ and ${ }^{208} \mathrm{~Pb} /{ }^{204} \mathrm{~Pb}$ ratios which are consistent with those of the NDZ eclogites and granitic orthogneisses (Figure 12). Thus, the studied migmatites were possibly derived from the subducted NDZ terrane; this interpretation is also supported by the occurrence of Neoproterozoic igneous and Triassic metamorphic zircons as mentioned above.

As shown in Figures 11 and 12, sample 1310YZH1-1 (Grt-bearing leucosome) exhibits higher whole-rock initial ${ }^{87} \mathrm{Sr} /{ }^{86} \mathrm{Sr},{ }^{206} \mathrm{~Pb} /{ }^{204} \mathrm{~Pb},{ }^{207} \mathrm{~Pb} /{ }^{204} \mathrm{~Pb}$ and ${ }^{208} \mathrm{~Pb} /{ }^{204} \mathrm{~Pb}$ ratios compared to other leucosomes, similar to those from the CDZ, suggestive of reworking of metamorphic fluids from the CDZ. In comparison with neodymium, strontium and lead are more easily reworked by metamorphic fluids (especially in the upper crust) during exhumation [116]. Moreover, REE and HFSE (such as Zr and $\mathrm{Nb}$ ) trends in sample 1310YZH1-1 coincide with other Grt-bearing leucosomes, while elements with high mobility in fluid (e.g., $\mathrm{Si}, \mathrm{Al}, \mathrm{K}, \mathrm{Na}, \mathrm{Rb}, \mathrm{Pb}, \mathrm{Ba}$ ) are significantly lower, certifying the influx of metamorphic fluids after crystallization [117-120].

Grt-bearing leucosomes exhibit high total REE contents with low La $/ \mathrm{Yb}_{\mathrm{N}}$ and negative Eu anomalies due to the presence of peritectic garnet and the lack of plagioclase. Biotite breakdown released $\mathrm{Rb}$ into the melt and increased the $\mathrm{Rb} / \mathrm{Sr}$ and $\mathrm{Rb} / \mathrm{Ba}$ ratio. However, because of the low abundance of free water in continental rocks under UHP conditions and of the scarcity of fluids released by minerals dehydration, only low volumes of melt could have been produced during anatexis of the NDZ in the Triassic. Considering the external fluid injection from the country rocks (CDZ) and the long-term heating in the Cretaceous, some of the Grt-bearing leucosomes were probably remelted or even disappeared during the subsequent events, while the surviving ones might have been altered to some extent. Furthermore, due to multistage metamorphic evolution and retrogression, the garnet and related minerals in the Grt-bearing leucosomes were transformed or decomposed by other minerals such as amphibole and plagioclase. As a result, the Grt-bearing leucosomes are rarely preserved in the NDZ.

Amp-rich, Amp-poor and Kfs-rich leucosomes display different REE patterns especially in HREE contents, Eu anomalies and $(\mathrm{La} / \mathrm{Yb})_{\mathrm{N}}$ ratios (Figure 6). Phosphate minerals and amphiboles can greatly affect whole-rock LREE contents while MREE and HREE are generally enriched in minerals such as zircon, garnet and amphibole [98,121]. Negative correlations between $\mathrm{P}_{2} \mathrm{O}_{5}$ and $\mathrm{SiO}_{2}$ contents (Figure 13b) suggest melts had carried phosphate minerals such as apatite and monazite during migration and evolution. Apatite displays higher $\mathrm{Sm} / \mathrm{Nd}$ ratios than monazite and is preferentially dissolved at relatively dry, higher-temperature conditions [122]. Sm/Nd ratios of most leucosomes are slightly lower than melanosomes (Figure 13c), indicating dissolution of monazite might have been more relevant than dissolution of apatite. Nevertheless, there is no obvious relationship between $\mathrm{P}_{2} \mathrm{O}_{5}$ and LREE contents (Figure 13d), proving that dissolution of phosphate minerals is not the dominant process controlling the LREE patterns. Besides, $\mathrm{Zr}$ contents of most leucosomes are lower than 330 ppm and exclude the possibility of zircon controlling whole-rock HREE contents. FeO $+\mathrm{MgO}_{\mathrm{T}}$ contents in leucosomes show positive correlation with LREE and HREE versus Y contents (Figure 13e,f), suggesting that the leucosomes REE contents are principally controlled by amphibole without garnet in the source rocks.

Amp-rich leucosomes contain abundant coarse-grained peritectic amphiboles and display high $\mathrm{REE}$ total contents with no distinct $\mathrm{Eu}$ anomalies, low $(\mathrm{La} / \mathrm{Yb})_{\mathrm{N}}$ ratios and lower $\mathrm{Sr} / \mathrm{Y}$ ratios. On the 
other hand, as amphiboles are more dominated by HREE and MREE than by LREE, Amp-poor leucosomes show no obvious Eu anomalies and steep HREE patterns with higher $(\mathrm{La} / \mathrm{Yb})_{\mathrm{N}}$ and $\mathrm{Sr} / \mathrm{Y}$ ratios due to the occurrence of depleted peritectic amphibole. Kfs-rich leucosomes exhibit significantly low total REE contents and pronounced positive Eu anomalies with $\delta_{\mathrm{Eu}}$ values ranging from 7.05 to 15.55, consistent with their Pl-rich and mafic-minerals-depleted assemblages. However, Amp-rich and -poor leucosomes have no sharp boundaries in chemical components or mineral compositions. Instead, there is more likely to be a gradual compositional change during melt fractional crystallization in consideration of the similarity of melanosomes pairing with different types of leucosomes. Potassium is a strongly incompatible element and prefers to migrate into melts than solids during partial melting and crystallization, resulting in the richer potassium content of terminal crystallized products than the initial ones $[123,124]$. Amp-rich, Amp-poor and Kfs-rich leucosomes display successive increase in $\mathrm{K}_{2} \mathrm{O}$ contents with averages of 3.34, 4.71 and $5.00 \mathrm{wt} . \%$, respectively, in spite of the quite few amphiboles modal content in Amp-poor and Kfs-rich leucosomes. The trends of Amp-decreasing and Kfs-increasing from Amp-rich to Amp-poor and then Kfs-rich leucosomes suggest K-feldspar became gradually a reservoir of potassium instead of amphibole. The inference is also supported by the reducing HREE and total REE contents and by the increasing Eu positive anomalies. In summary, Amp-rich, Amp-poor and Kfs-rich leucosomes are extensively widespread in the NDZ and they are products of different stages of fractional crystallization of Cretaceous anatectic melts as proposed by [125].

\section{Conclusions}

The migmatites in the NDZ contain at least four groups of leucosomes: (1) Grt-bearing leucosomes; (2) Amp-rich leucosomes; (3) Amp-poor leucosomes and (4) Kfs-rich leucosomes. Grt-bearing leucosomes were formed at $209 \pm 2$ Ma through fluid-absent decompression melting during the initial stage of exhumation and derived from biotite dehydration melting under granulite-facies conditions. Mountain-root collapse of the Dabie orogen and asthenosphere upwelling with long-term heating and external aqueous fluid influx in the Cretaceous resulted in large-scale partial melting of the NDZ (especially of the granitic gneisses) under amphibolite-facies conditions. The Cretaceous anatexis initiated at $143 \pm 2 \mathrm{Ma}$ as a consequence of fluid-fluxed heating melting, and Amp-rich and -poor leucosomes subsequently crystallized at approximately $138 \pm 124 \mathrm{Ma}$ along with the changing of temperature and $\mathrm{H}_{2} \mathrm{O}$ activity. At the final stage of post-orogenic collapse at ca. $117 \mathrm{Ma}$ with a further temperature decrease and crossing of the wet solidus, Kfs-rich leucosomes crystallized from the residual melts with accumulation of plagioclase and quartz. Although the various generations of leucosomes exhibit to some extent difference in field occurrences, mineral assemblages and geochemical characters, the whole-rock $\mathrm{Sr}-\mathrm{Nd}-\mathrm{Pb}$ isotopic compositions and zircon geochronological dating document that all the leucosomes have similar sources, i.e., the Triassic subducted Neoproterozoic lower-crustal rocks.

Supplementary Materials: The following are available online at http://www.mdpi.com/2075-163X/10/7/618/s1, Table S1: Major and trace elements compositions of various leucosomes and melanosomes in stromatic migmatites in the NDZ, Table S2: SHRIMP zircon U-Pb data for Grt-bearing, Amp-rich and Amp-poor leucosomes from the NDZ, Table S3: LA-ICPMS zircon U-Pb data for Kfs-rich leucosomes and migmatites from the NDZ, Table S4: $\mathrm{Sr}-\mathrm{Nd}-\mathrm{Pb}$ isotopic compositions of various leucosomes and melanosomes in stromatic migmatites in the NDZ, Table S5: Electron microprobe analyses of representative minerals from various leucosomes in the NDZ.

Author Contributions: Y.Y., Y.-C.L., Y.L., C.G. and F.R. wrote the paper; funding acquisition, Y.-C.L.; field investigation, Y.Y., Y.-C.L. and Y.L.; methodology, Y.Y. and Y.-C.L.; project administration, Y.-C.L. All authors have read and agreed to the published version of the manuscript.

Funding: This work was supported by funds from the National Natural Science Foundation of China (41273036 and 41773020) and the National Basic Research Program of China (2015CB856104).

Acknowledgments: The authors thank B. Song and C. Yang for help in SHRIMP U-Pb dating on zircon, F.-K. Chen for the Raman and $\mathrm{Sr}-\mathrm{Nd}-\mathrm{Pb}$ isotopic analysis and Y.-H. Shi and J. Wang for the electron microprobe analysis. We are grateful to Assistant Editor for editor handing and two anonymous reviewers for their many helpful comments and suggestions that greatly helped to improve an earlier version of the manuscript. 
Conflicts of Interest: The authors declare no conflict of interest.

\section{References}

1. Hollister, L.S. The role of melt in the uplift and exhumation of orogenic belts. Chem. Geol. 1993, 108, 31-48. [CrossRef]

2. Whitney, D.L.; Teyssier, C.; Rey, P. The consequences of crustal melting in continental subduction. Lithosphere 2009, 1, 323-327. [CrossRef]

3. Brown, M. The generation, segregation, ascent and emplacement of granite magma: The migmatite-to -crustally-derived granite connection in thickened orogens. Earth-Sci. Rev. 1994, 36, 83-130. [CrossRef]

4. Dobretsov, N.L.; Shatsky, V.S. Exhumation of high-pressure rocks of the Kokchetav massif: Facts and models. Lithos 2004, 78, 307-318. [CrossRef]

5. Liu, Y.-C.; Deng, L.; Gu, X. Multistage exhumation and partial melting of high-T ultrahigh-pressure metamorphic rocks in continental subduction-collision zones. Sci. China Earth Sci. 2015, 58, 1084-1099. [CrossRef]

6. Rey, P.; Vanderhaeghe, O.; Teyssier, C. Gravitational collapse of the continental crust: Definition, regimes and modes. Tectonophysics 2001, 342, 435-449. [CrossRef]

7. Vanderhaeghe, O.; Teyssier, C. Partial melting and flow of orogens. Tectonophysics 2001, 342, 451-472. [CrossRef]

8. Huw Davies, J.; von Blanckenburg, F. Slab breakoff: A model of lithosphere detachment and its test in the magmatism and deformation of collisional orogens. Earth Planet. Sci. Lett. 1995, 129, 85-102. [CrossRef]

9. Dewey, J.F. Extensional collapse of orogens. Tectonics 1988, 7, 1123-1139. [CrossRef]

10. England, P.C.; Thompson, A.B. Pressure-Temperature-Time Paths of Regional Metamorphism I. Heat Transfer during the Evolution of Regions of Thickened Continental Crust. J. Petrol. 1984, 25, 894-928. [CrossRef]

11. Gao, S.; Rudnick, R.L.; Yuan, H.-L.; Liu, X.-M.; Liu, Y.-S.; Xu, W.-L.; Ling, W.-L.; Ayers, J.; Wang, X.-C.; Wang, Q.-H. Recycling lower continental crust in the North China craton. Nature 2004, 432, 892-897. [CrossRef] [PubMed]

12. Huppert, H.E.; Sparks, R.S.J. The Generation of Granitic Magmas by Intrusion of Basalt into Continental Crust. J. Petrol. 1988, 29, 599-624. [CrossRef]

13. Turner, S.; Arnaud, N.; Liu, J.; Rogers, N.; Hawkesworth, C.; Harris, N.; Kelley, S.; Van Calsteren, P.; Deng, W. Post-collision, Shoshonitic Volcanism on the Tibetan Plateau: Implications for Convective Thinning of the Lithosphere and the Source of Ocean Island Basalts. J. Petrol. 1996, 37, 45-71. [CrossRef]

14. Arzi, A.A. Critical phenomena in the rheology of partially melted rocks. Tectonophysics 1978, 44, $173-184$. [CrossRef]

15. Holyoke, C.W., III; Rushmer, T. An experimental study of grain scale melt segregation mechanisms in two common crustal rock types. J. Metamorph. Geol. 2002, 20, 493-512. [CrossRef]

16. Rosengerg, C.L.; Handy, M.R. Experimental deformation of partially melted granite revisited: Implications for the continental crust. J. Metamorph. Geol. 2005, 23, 19-28. [CrossRef]

17. Vanderhaeghe, O. Migmatites, granites and orogeny: Flow modes of partially-molten rocks and magmas associated with melt/solid segregation in orogenic belts. Tectonophysics 2009, 477, 119-134. [CrossRef]

18. Hermann, J.; Rubatto, D.; Korsakov, A.; Shatsky, V.S. Multiple zircon growth during fast exhumation of diamondiferous, deeply subducted continental crust (Kokchetav Massif, Kazakhstan). Contrib. Mineral. Petrol. 2001, 141, 66-82. [CrossRef]

19. Jamieson, R.A.; Unsworth, M.J.; Harris, N.B.W.; Rosenberg, C.L.; Schulmann, K. Crustal Melting and the Flow of Mountains. Elements 2011, 7, 253-260. [CrossRef]

20. Labrousse, L.; Prouteau, G.; Ganzhorn, A.-C. Continental exhumation triggered by partial melting at ultrahigh pressure. Geology 2011, 39, 1171-1174. [CrossRef]

21. Wallis, S.; Tsuboi, M.; Suzuki, K.; Fanning, M.; Jiang, L.; Tanaka, T. Role of partial melting in the evolution of the Sulu (eastern China) ultrahigh-pressure terrane. Geology 2005, 33, 129-132. [CrossRef]

22. Barraud, J.; Gardien, V.; Allemand, P.; Grandjean, P. Analogue models of melt-flow networks in folding migmatites. J. Struct. Geol. 2004, 26, 307-324. [CrossRef] 
23. Hinchey, A.M.; Carr, S.D.; McNeill, P.D.; Rayner, N. Paleocene-Eocene high-grade metamorphism, anatexis, and deformation in the Thor-Odin dome, Monashee complex, southeastern British Columbia. Can. J. Earth Sci. 2006, 43, 1341-1365. [CrossRef]

24. Auzanneau, E.; Vielzeuf, D.; Schmidt, M.W. Experimental evidence of decompression melting during exhumation of subducted continental crust. Contrib. Mineral. Petrol. 2006, 152, 125-148. [CrossRef]

25. Büsch, W.; Schenider, G.; Mehnert, K. Initial melting at grain boundaries. Part II: Melting in rocks of granodioritic, quartzdioritic and tonalitic composition. Neues Jahrb. Mineral. Mon. 1974, 8, 345-370.

26. Perchuk, A.L.; Burchard, M.; Maresch, W.V.; Schertl, H.-P. Fluid-mediated modification of garnet interiors under ultrahigh-pressure conditions. Terra Nova 2005, 17, 545-553. [CrossRef]

27. Del Moro, A.; Fornelli, A.; Piccarreta, G. Disequilibrium melting in granulite-facies metasedimentary rocks of the Northern Serre (Calabria-Southern Italy). Mineral. Petrol. 2000, 70, 89-104. [CrossRef]

28. Liu, Y.-C.; Li, S.-G.; Gu, X.-F.; Xu, S.-T.; Chen, G.-B. Ultrahigh-pressure eclogite transformed from mafic granulite in the Dabie orogen, east-central China. J. Metamorph. Geol. 2007, 25, 975-989. [CrossRef]

29. Liu, Y.-C.; Li, S.-G.; Xu, S.-T. Zircon SHRIMP U-Pb dating for gneisses in northern Dabie high T/P metamorphic zone, central China: Implications for decoupling within subducted continental crust. Lithos 2007, 96, 170-185. [CrossRef]

30. Liu, Y.-C.; Deng, L.-P.; Gu, X.-F.; Groppo, C.; Rolfo, F. Application of Ti-in-zircon and Zr-in-rutile thermometers to constrain high-temperature metamorphism in eclogites from the Dabie orogen, central China. Gondwana Res. 2015, 27, 410-423. [CrossRef]

31. Hacker, B.R.; Ratschbacher, L.; Webb, L.; Ireland, T.; Walker, D.; Shuwen, D. U/Pb zircon ages constrain the architecture of the ultrahigh-pressure Qinling-Dabie Orogen, China. Earth Planet. Sci. Lett. 1998, 161, 215-230. [CrossRef]

32. Wang, J.; Sun, M.; Deng, S. Geochronological constraints on the timing of migmatization in the Dabie Shan, East-central China. Eur. J. Mineral. 2002, 14, 513-524. [CrossRef]

33. Faure, M.; Lin, W.; Schärer, U.; Shu, L.; Sun, Y.; Arnaud, N. Continental subduction and exhumation of UHP rocks. Structural and geochronological insights from the Dabieshan (East China). Lithos 2003, 70, $213-241$. [CrossRef]

34. Wu, Y.-B.; Zheng, Y.-F.; Zhang, S.-B.; Zhao, Z.-F.; Wu, F.-Y.; Liu, X.-M. Zircon U-Pb ages and Hf isotope compositions of migmatite from the North Dabie terrane in China: Constraints on partial melting. J. Metamorph. Geol. 2007, 25, 991-1009. [CrossRef]

35. Wang, S.-J.; Li, S.-G.; Chen, L.-J.; He, Y.-S.; An, S.-C.; Shen, J. Geochronology and geochemistry of leucosomes in the North Dabie Terrane, East China: Implication for post-UHPM crustal melting during exhumation. Contrib. Mineral. Petrol. 2013, 165, 1009-1029. [CrossRef]

36. Chen, R.-X.; Ding, B.; Zheng, Y.-F.; Hu, Z. Multiple episodes of anatexis in a collisional orogen: Zircon evidence from migmatite in the Dabie orogen. Lithos 2015, 212-215, 247-265. [CrossRef]

37. Hu, Z.-P.; Zhang, Y.-S.; Hu, R.; Wang, J.; Siebel, W.; Chen, F. Amphibole-bearing migmatite in North Dabie, eastern China: Water-fluxed melting of the orogenic crust. J. Asian Earth Sci. 2016, 125, 100-116. [CrossRef]

38. Xu, H.; Zhang, J. Anatexis witnessed post-collisional evolution of the Dabie orogen, China. J. Asian Earth Sci. 2017, 145, 278-296. [CrossRef]

39. He, Y.; Li, S.; Hoefs, J.; Huang, F.; Liu, S.-A.; Hou, Z. Post-collisional granitoids from the Dabie orogen: New evidence for partial melting of a thickened continental crust. Geochim. Et Cosmochim. Acta 2011, 75, 3815-3838. [CrossRef]

40. Deng, L.-P.; Liu, Y.-C.; Gu, X.-F.; Groppo, C.; Rolfo, F. Partial melting of ultrahigh-pressure metamorphic rocks at convergent continental margins: Evidences, melt compositions and physical effects. Geosci. Front. 2018, 9, 1229-1242. [CrossRef]

41. Deng, L.-P.; Liu, Y.-C.; Yang, Y.; Groppo, C.; Rolfo, F.; Gu, X.-F. Anatexis of high-T eclogites in the Dabie orogen triggered by exhumation and post-orogenic collapse. Eur. J. Mineral. 2019, 31, 889-903. [CrossRef]

42. Li, Y.; Yang, Y.; Liu, Y.-C.; Groppo, C.; Rolfo, F. Muscovite Dehydration Melting in Silica-Undersaturated Systems: A Case Study from Corundum-Bearing Anatectic Rocks in the Dabie Orogen. Minerals 2020, 10, 213. [CrossRef]

43. Li, S.; Xiao, Y.; Liou, D.; Chen, Y.; Ge, N.; Zhang, Z.; Sun, S.-S.; Cong, B.; Zhang, R.; Hart, S.R.; et al. Collision of the North China and Yangtse Blocks and formation of coesite-bearing eclogites: Timing and processes. Chem. Geol. 1993, 109, 89-111. [CrossRef] 
44. Xu, S.; Okay, A.I.; Ji, S.; Sengör, A.M.C.; Su, W.; Liu, Y.-C.; Jiang, L. Diamond from the Dabie Shan Metamorphic Rocks and Its Implication for Tectonic Setting. Science 1992, 256, 80-82. [CrossRef]

45. Liu, Y.-C.; Li, S. Detachment within subducted continental crust and multi-slice successive exhumation of ultrahigh-pressure metamorphic rocks: Evidence from the Dabie-Sulu orogenic belt. Chin. Sci. Bull. 2008, 53, 3105-3119. [CrossRef]

46. Liu, Y.-C.; Liu, L.-X.; Li, Y.; Gu, X.-F.; Song, B. Zircon U-Pb geochronology and petrogenesis of metabasites from the western Beihuaiyang zone in the Hong'an orogen, central China: Implications for detachment within subducting continental crust at shallow depths. J. Asian Earth Sci. 2017, 145, 74-90. [CrossRef]

47. Xu, S.; Liu, Y.; Chen, G.; Compagnoni, R.; Rolfo, F.; He, M.; Liu, H. New finding of micro-diamonds in eclogites from Dabie-Sulu region in central-eastern China. Sci. Bull. 2003, 48, 988-994. [CrossRef]

48. Xu, S.; Liu, Y.; Chen, G.; Ji, S.; Ni, P.; Xiao, W. Microdiamonds, their classification and tectonic implications for the host eclogites from the Dabie and Su-Lu regions in central eastern China. Mineral. Mag. 2005, 69, 509-520. [CrossRef]

49. Groppo, C.; Rolfo, F.; Liu, Y.-C.; Deng, L.-P.; Wang, A.-D. P-T evolution of elusive UHP eclogites from the Luotian dome (North Dabie Zone, China): How far can the thermodynamic modeling lead us? Lithos 2015, 226, 183-200. [CrossRef]

50. Li, X.-P.; Zheng, Y.-F.; Wu, Y.-B.; Chen, F.; Gong, B.; Li, Y.-L. Low-T eclogite in the Dabie terrane of China: Petrological and isotopic constraints on fluid activity and radiometric dating. Contrib. Mineral. Petrol. 2004, 148, 443-470. [CrossRef]

51. Liu, Y.-C.; Li, S.; Xu, S.; Jahn, B.-m.; Zheng, Y.-F.; Zhang, Z.; Jiang, L.; Chen, G.; Wu, W. Geochemistry and geochronology of eclogites from the northern Dabie Mountains, central China. J. Asian Earth Sci. 2005, 25, 431-443. [CrossRef]

52. Liu, Y.-C.; Gu, X.; Rolfo, F.; Chen, Z. Ultrahigh-pressure metamorphism and multistage exhumation of eclogite from the Luotian dome, North Dabie Complex Zone (central China): Evidence from mineral inclusions and decompression texture. J. Asian Earth Sci. 2011, 42, 607-617. [CrossRef]

53. Okay, A.I.; Xu, S.T.; Sengor, A.M.C. Coesite from the Dabie Shan eclogites, central China. Eur. J. Mineral. 1989, 1, 595-598. [CrossRef]

54. Rolfo, F.; Compagnoni, R.; Wu, W.; Xu, S. A coherent lithostratigraphic unit in the coesite-eclogite complex of Dabie Shan, China: Geologic and petrologic evidence. Lithos 2004, 73, 71-94. [CrossRef]

55. Wang, X.; Liou, J.G.; Mao, H. Coesite-bearing eclogite from the Dabie Mountains in central China. Geology 1989, 17, 1085-1088. [CrossRef]

56. Xu, S.; Liu, Y.; Su, W.; Wang, R.; Jiang, L.; Wu, W. Discovery of the eclogite and its petrography in the Northern Dabie Mountain. Chin. Sci. Bull. 2000, 45, 273-278. [CrossRef]

57. Li, S.; Jagoutz, E.; Chen, Y.; Li, Q. Sm-Nd and Rb-Sr isotopic chronology and cooling history of ultrahigh pressure metamorphic rocks and their country rocks at Shuanghe in the Dabie Mountains, Central China. Geochim. Cosmochim. Acta 2000, 64, 1077-1093. [CrossRef]

58. Liu, Y.-C.; Gu, X.-F.; Li, S.-G.; Hou, Z.-H.; Song, B. Multistage metamorphic events in granulitized eclogites from the North Dabie complex zone, central China: Evidence from zircon $\mathrm{U}-\mathrm{Pb}$ age, trace element and mineral inclusion. Lithos 2011, 122, 107-121. [CrossRef]

59. Malaspina, N.; Hermann, J.; Scambelluri, M.; Compagnoni, R. Multistage metasomatism in ultrahigh-pressure mafic rocks from the North Dabie Complex (China). Lithos 2006, 90, 19-42. [CrossRef]

60. Li, S.G.; He, Y.S.; Wang, S.J. Process and mechanism of mountain-root removal of the Dabie Orogen Constraints from geochronology and geochemistry of post-collisional igneous rocks. Chin. Sci. Bull. 2013, 58, 4411-4417. [CrossRef]

61. Sawyer, E.W. Migmatites formed by water-fluxed partial melting of a leucogranodiorite protolith: Microstructures in the residual rocks and source of the fluid. Lithos 2010, 116, 273-286. [CrossRef]

62. Black, L.P.; Kamo, S.L.; Allen, C.M.; Aleinikoff, J.N.; Davis, D.W.; Korsch, R.J.; Foudoulis, C. TEMORA 1: A new zircon standard for Phanerozoic U-Pb geochronology. Chem. Geol. 2003, 200, 155-170. [CrossRef]

63. Compston, W.; Williams, I.S.; Meyer, C. U-Pb geochronology of zircons from lunar breccia 73217 using a sensitive high mass-resolution ion microprobe. J. Geophys. Res. Solid Earth 1984, 89, B525-B534. [CrossRef]

64. Ludwig, K.R. User's Manual for Isoplot 3.00: A Geochronological Tookit for Microsoft Excel; Berkeley Geochronology Center Special Publication: Berkeley, CA, USA, 2003; Volume 4. 
65. Liu, Y.; Hu, Z.; Gao, S.; Günther, D.; Xu, J.; Gao, C.; Chen, H. In situ analysis of major and trace elements of anhydrous minerals by LA-ICP-MS without applying an internal standard. Chem. Geol. 2008, 257, 34-43. [CrossRef]

66. Liu, Y.; Gao, S.; Hu, Z.; Gao, C.; Zong, K.; Wang, D. Continental and Oceanic Crust Recycling-induced Melt-Peridotite Interactions in the Trans-North China Orogen: U-Pb Dating, Hf Isotopes and Trace Elements in Zircons from Mantle Xenoliths. J. Petrol. 2009, 51, 537-571. [CrossRef]

67. Chen, F.; Hegner, E.; Todt, W. Zircon ages and Nd isotopic and chemical compositions of orthogneisses from the Black Forest, Germany: Evidence for a Cambrian magmatic arc. Int. J. Earth Sci. 2000, 88, 791-802. [CrossRef]

68. Chen, F.; Li, X.-H.; Wang, X.-L.; Li, Q.-L.; Siebel, W. Zircon age and Nd-Hf isotopic composition of the Yunnan Tethyan belt, southwestern China. Int. J. Earth Sci. 2007, 96, 1179-1194. [CrossRef]

69. Whitney, D.L.; Evans, B.W. Abbreviations for names of rock-forming minerals. Am. Mineral. 2010, 95, $185-187$. [CrossRef]

70. Boynton, W.V. Geochemistry of the Rare Earth Elements: Meteorite Study. In Rare Earth Element Geochemistry; Henderson, P., Ed.; Elsevier: Amsterdam, The Netherlands, 1984; pp. 63-114.

71. Sun, S.-s.; McDonough, W.F. Chemical and isotopic systematics of oceanic basalts: Implications for mantle composition and processes. Geol. Soc. 1989, 42, 313-345. [CrossRef]

72. Liu, X.; Yan, J.; Yang, G. Geochronology and geochemistry of the Sikongshan intrusion in the Dabie Orogen, Central China: Implication for Mesozoic geodynamic background. Geol. J. 2020, 55, 3010-3035. [CrossRef]

73. Lustrino, M.; Dallai, L. On the origin of EM-I end-member. Neues Jahrb. Mineral. Abh. 2003, 179, 85-100. [CrossRef]

74. Moyen, J.F.; Stevens, G. Experimental Constraints on TTG Petrogenesis: Implications for Archean Geodynamics. Archean Geodynamics and Environments; American Geophysical Union (AGU): Washington, DC, USA, 2006.

75. Clemens, J.; Watkins, J. The fluid regime of high-temperature metamorphism during granitoid magma genesis. Contrib. Mineral. Petrol. 2001, 140, 600-606. [CrossRef]

76. Rutter, M.J.; Wyllie, P.J. Melting of vapour-absent tonalite at $10 \mathrm{kbar}$ to simulate dehydration-melting in the deep crust. Nature 1988, 331, 159-160. [CrossRef]

77. Fornelli, A.; Piccarreta, G.; Del Moro, A.; Acquafredda, P. Multi-stage Melting in the Lower Crust of the Serre (Southern Italy). J. Petrol. 2002, 43, 2191-2217. [CrossRef]

78. Dahlquist, J.A.; Galindo, C.; Pankhurst, R.J.; Rapela, C.W.; Alasino, P.H.; Saavedra, J.; Fanning, C.M. Magmatic evolution of the Peñón Rosado granite: Petrogenesis of garnet-bearing granitoids. Lithos 2007, 95, 177-207. [CrossRef]

79. Leake, B.E. Zoned garnets from the galway granite and its aplites. Earth Planet. Sci. Lett. 1967, 3, 311-316. [CrossRef]

80. Villaros, A.; Stevens, G.; Buick, I.S. Tracking S-type granite from source to emplacement: Clues from garnet in the Cape Granite Suite. Lithos 2009, 112, 217-235. [CrossRef]

81. Watson, E.B.; Harrison, T.M. Zircon saturation revisited: Temperature and composition effects in a variety of crustal magma types. Earth Planet. Sci. Lett. 1983, 64, 295-304. [CrossRef]

82. Dale, J.; Holland, T.; Powell, R. Hornblende-garnet-plagioclase thermobarometry: A natural assemblage calibration of the thermodynamics of hornblende. Contrib. Mineral. Petrol. 2000, 140, 353-362. [CrossRef]

83. Patino Douce, A.E.; Beard, J.S. Dehydration-melting of Biotite Gneiss and Quartz Amphibolite from 3 to 15 kbar. J. Petrol. 1995, 36, 707-738. [CrossRef]

84. Patino Douce, A.E.; Beard, J.S. Effects of $\mathrm{P}, \mathrm{f}(\mathrm{O} 2)$ and $\mathrm{Mg} / \mathrm{Fe}$ Ratio on Dehydration Melting of Model Metagreywackes. J. Petrol. 1996, 37, 999-1024. [CrossRef]

85. Weinberg, R.F.; Veveakis, E.; Regenauerlieb, K. Compaction-driven melt segregation in migmatites. Geology 2015, 43, 471-474. [CrossRef]

86. Sawyer, E.W. Altas of Migmatites; NRC Research Press: Ottowa, ON, Canada, 2008; Volume 9.

87. Slagstad, T.; Jamieson, R.A.; Culshaw, N.G. Formation, Crystallization, and Migration of Melt in the Mid-orogenic Crust: Muskoka Domain Migmatites, Grenville Province, Ontario. J. Petrol. 2005, 46, 893-919. [CrossRef]

88. Berger, A.; Burri, T.; Alt-Epping, P.; Engi, M. Tectonically controlled fluid flow and water-assisted melting in the middle crust: An example from the Central Alps. Lithos 2008, 102, 598-615. [CrossRef] 
89. Cruciani, G.; Franceschelli, M.; Jung, S.; Puxeddu, M.; Utzeri, D. Amphibole-bearing migmatites from the Variscan Belt of NE Sardinia, Italy: Partial melting of mid-Ordovician igneous sources. Lithos 2008, 105, 208-224. [CrossRef]

90. Aubaud, C.; Hauri, E.H.; Hirschmann, M.M. Hydrogen partition coefficients between nominally anhydrous minerals and basaltic melts. Geophys. Res. Lett. 2004, 31, L20611. [CrossRef]

91. Hirschmann, M.M.; Tenner, T.; Aubaud, C.; Withers, A.C. Dehydration melting of nominally anhydrous mantle: The primacy of partitioning. Phys. Earth Planet. Inter. 2009, 176, 54-68. [CrossRef]

92. Naney, M.T. Phase equilibria of rock-forming ferromagnesian silicates in granitic systems. Am. J. Sci. 1983, 283, 993-1033. [CrossRef]

93. Johnston, A.D.; Wyllie, P.J. Constraints on the origin of Archean trondhjemites based on phase relationships of Nûk gneiss with H2O at 15 kbar. Contrib. Mineral. Petrol. 1988, 100, 35-46. [CrossRef]

94. Skjerlie, K.P.; Johnston, A.D. Vapour-Absent Melting from 10 to 20 kbar of Crustal Rocks that Contain Multiple Hydrous Phases: Implications for Anatexis in the Deep to Very Deep Continental Crust and Active Continental Margins. J. Petrol. 1996, 37, 661-691. [CrossRef]

95. Brown, M. Metamorphic patterns in orogenic systems and the geological record. Geol. Soc. 2009, 318, 37-74. [CrossRef]

96. Burri, T.; Berger, A.; Engi, M. Tertiary migmatites in the central Alps: Regional distribution, field relations, conditions of formation, and tectonic implications. Schweiz. Mineral. Petrogr. Mitt. 2005, 85, 215-232.

97. Mogk, D.W. Ductile shearing and migmatization at mid-crustal levels in an Archaean high-grade gneiss belt, northern Gallatin Range, Montana, USA. J. Metamorph. Geol. 1992, 10, 427-438. [CrossRef]

98. Bea, F.; Pereira, M.D.; Stroh, A. Mineral/leucosome trace-element partitioning in a peraluminous migmatite (a laser ablation-ICP-MS study). Chem. Geol. 1994, 117, 291-312. [CrossRef]

99. Neiva, A.M.R. Distribution of trace elements in feldspars of granitic aplites and pegmatites from Alijó-Sanfins, northern Portugal. Mineral. Mag. 1995, 59, 35-45. [CrossRef]

100. Harrison, M.T.; Grove, M.; Mckeegan, K.D.; Coath, C.D.; Lovera, O.M.; Fort, P.L. Origin and Episodic Emplacement of the Manaslu Intrusive Complex, Central Himalaya. J. Petrol. 1999, 40, 3-19. [CrossRef]

101. Schmidt, M.W. Amphibole composition in tonalite as a function of pressure: An experimental calibration of the Al-in-hornblende barometer. Contrib. Mineral. Petrol. 1992, 110, 304-310. [CrossRef]

102. Holland, T.; Blundy, J. Non-ideal interactions in calcic amphiboles and their bearing on amphibole-plagioclase thermometry. Contrib. Mineral. Petrol. 1994, 116, 433-447. [CrossRef]

103. Hermann, J.; Spandler, C.; Hack, A.; Korsakov, A.V. Aqueous fluids and hydrous melts in high-pressure and ultra-high pressure rocks: Implications for element transfer in subduction zones. Lithos 2006, 92, 399-417. [CrossRef]

104. Ames, L.; Gaozhi, Z.; Baocheng, X. Geochronology and isotopic character of ultrahigh-pressure metamorphism with implications for collision of the Sino-Korean and Yangtze cratons, central China. Tectonics 1996, 15, 472-489. [CrossRef]

105. Wlillams, I.S.; Buick, I.S.; Cartwright, I. An extended episode of early Mesoproterozoic metamorphic fluid flow in the Reynolds Range, central Australia. J. Metamorph. Geol. 1996, 14, 29-47. [CrossRef]

106. Hoskin, P.W.O.; Schaltegger, U. The Composition of Zircon and Igneous and Metamorphic Petrogenesis. Rev. Mineral. Geochem. 2003, 53, 27-62. [CrossRef]

107. Rubatto, D.; Hermann, J. Zircon formation during fluid circulation in eclogites (Monviso, Western Alps): Implications for $\mathrm{Zr}$ and $\mathrm{Hf}$ budget in subduction zones. Geochim. Cosmochim. Acta 2003, 67, 2173-2187. [CrossRef]

108. Burda, J.; Gawęda, A. Shear-influenced partial melting in the Western Tatra metamorphic complex: Geochemistry and geochronology. Lithos 2009, 110, 373-385. [CrossRef]

109. Reno, B.L.; Piccoli, P.M.; Brown, M.; Trouw, R.A.J. In situ monazite (U-Th)-Pb ages from the Southern Brasília Belt, Brazil: Constraints on the high-temperature retrograde evolution of HP granulites. J. Metamorph. Geol. 2012, 30, 81-112. [CrossRef]

110. Brown, M.; Solar, G.S. Shear-zone systems and melts: Feedback relations and self-organization in orogenic belts. J. Struct. Geol. 1998, 20, 211-227. [CrossRef]

111. Brown, M.; Solar, G.S. Granite ascent and emplacement during contractional deformation in convergent orogens. J. Struct. Geol. 1998, 20, 1365-1393. [CrossRef] 
112. Marchildon, N.; Brown, M. Spatial distribution of melt-bearing structures in anatectic rocks from Southern Brittany, France: Implications for melt transfer at grain- to orogen-scale. Tectonophysics 2003, 364, 215-235. [CrossRef]

113. Solar, G.S.; Brown, M. Petrogenesis of Migmatites in Maine, USA: Possible Source of Peraluminous Leucogranite in Plutons? J. Petrol. 2001, 42, 789-823. [CrossRef]

114. Li, Y.; Liu, Y.-C.; YANG, Y.; Deng, L. New U-Pb Geochronological Constraints on Formation and Evolution of the Susong Complex Zone in the Dabie Orogen. Acta Geol. Sin. (Engl. Ed.) 2017, 91, 1915-1918. [CrossRef]

115. Li, Y.; Liu, Y.-C.; Yang, Y.; Rolfo, F.; Groppo, C. Petrogenesis and tectonic significance of Neoproterozoic meta-basites and meta-granitoids within the central Dabie UHP zone, China: Geochronological and geochemical constraints. Gondwana Res. 2020, 78, 1-19. [CrossRef]

116. Shen, J.; Wang, Y.; Li, S.-G. Common Pb isotope mapping of UHP metamorphic zones in Dabie orogen, Central China: Implication for Pb isotopic structure of subducted continental crust. Geochim. Cosmochim. Acta 2014, 143, 115-131. [CrossRef]

117. Ague, J.J. Evidence for major mass transfer and volume strain during regional metamorphism of pelites. Geology 1991, 19, 855-858. [CrossRef]

118. Becker, H.; Jochum, K.P.; Carlson, R.W. Constraints from high-pressure veins in eclogites on the composition of hydrous fluids in subduction zones. Chem. Geol. 1999, 160, 291-308. [CrossRef]

119. Ferry, J.M. Mineral reactions and element migration during metamorphism of calcareous sediments from the Vassalboro Formation, south-central Maine. Am. Mineral. 1983, 68, 334-354.

120. Tang, H.F.; Liu, C.Q.; Xie, G.G. Mass transfer and element mobility of rocks during regional metamorphism: A case study of metamorphosed pelites from the Shuangqiaoshan Group in Lushan. Geol. Rev. 2000, 46, 245-254.

121. Ayres, M.; Harris, N. REE fractionation and Nd-isotope disequilibrium during crustal anatexis: Constraints from Himalayan leucogranites. Chem. Geol. 1997, 139, 249-269. [CrossRef]

122. Zeng, L.; Saleeby, J.B.; Asimow, P.D. Nd isotope disequilibrium during crustal anatexis: A record from the Goat Ranch migmatite complex, southern Sierra Nevada batholith, California. Geology 2005, 33, 53-56. [CrossRef]

123. Beard, J.S.; Lofgren, G.E. Dehydration Melting and Water-Saturated Melting of Basaltic and Andesitic Greenstones and Amphibolites at 1,3, and $6.9 \mathrm{~kb}$. J. Petrol. 1991, 32, 365-401. [CrossRef]

124. Watkins, J.M.; Clemens, J.D.; Treloar, P.J. Archaean TTGs as sources of younger granitic magmas: Melting of sodic metatonalites at 0.6-1.2 GPa. Contrib. Mineral. Petrol. 2007, 154, 91-110. [CrossRef]

125. Sawyer, E.W. Criteria for the recognition of partial melting. Phys. Chem. Earthpart A Solid Earth Geod. 1999, 24, 269-279. [CrossRef]

(C) 2020 by the authors. Licensee MDPI, Basel, Switzerland. This article is an open access article distributed under the terms and conditions of the Creative Commons Attribution (CC BY) license (http://creativecommons.org/licenses/by/4.0/). 